\title{
A novel nanoemulsion based microalgal growth medium for enhanced biomass production
}

\author{
Harshita Nigam \\ Indian Institute of Technology Delhi \\ Anushree Malik \\ Indian Institute of Technology Delhi https://orcid.org/0000-0002-2761-0568 \\ Vikram Singh ( $\sim$ vs225@chemical.iitd.ac.in ) \\ Indian Institute of Technology Delhi
}

\section{Research}

Keywords: Microalgae, Nanoemulsion, Paraffin oil, Silicone oil, Biomass

Posted Date: December 28th, 2020

DOl: https://doi.org/10.21203/rs.3.rs-43578/v2

License: (1) This work is licensed under a Creative Commons Attribution 4.0 International License.

Read Full License

Version of Record: A version of this preprint was published at Biotechnology for Biofuels on April 30th, 2021. See the published version at https://doi.org/10.1186/s13068-021-01960-8. 
1 Title: A novel nanoemulsion based microalgal growth medium for enhanced biomass

2 production

3 Harshita Nigam ${ }^{1}$, Anushree Malik ${ }^{1 *}$, Vikram Singh $^{2 *}$

$4{ }^{1}$ Applied Microbiology Laboratory, Centre for Rural Development and Technology and $5 \quad{ }^{2}$ Complex Fluid Lab, Department of Chemical Engineering, Indian Institute of Technology Delhi,

$6 \quad$ New Delhi, Hauz Khas, New Delhi 110016, India

Email address:

harshitanigam31@gmail.com (H. Nigam)

anushree@ rdat.iitd.ac.in (A. Malik)

vs225@chemical.iitd.ac.in (Vikram Singh) 
7 Corresponding author:

8 1. Assistant Prof.Vikram Singh*

9 Address: Room No- 377, Block II

10 Department of Chemical Engineering, Indian Institute of Technology Delhi, Hauz Khas, New

11 Delhi 110016, India

12 Phone: +91 8586809653, +911126591030

13 Email: vs225@chemical.iitd.ac.in,

14 Prof. Anushree Malik*

15 Address: Room No- 271, Block III

16 Centre for Rural Development and Technology, Indian Institute of Technology Delhi,

17 Hauz Khas, New Delhi 110016, India

18 Phone: +91 9968294221

19 Email: anushree@rdat.iitd.ac.in 
Graphical Abstract:

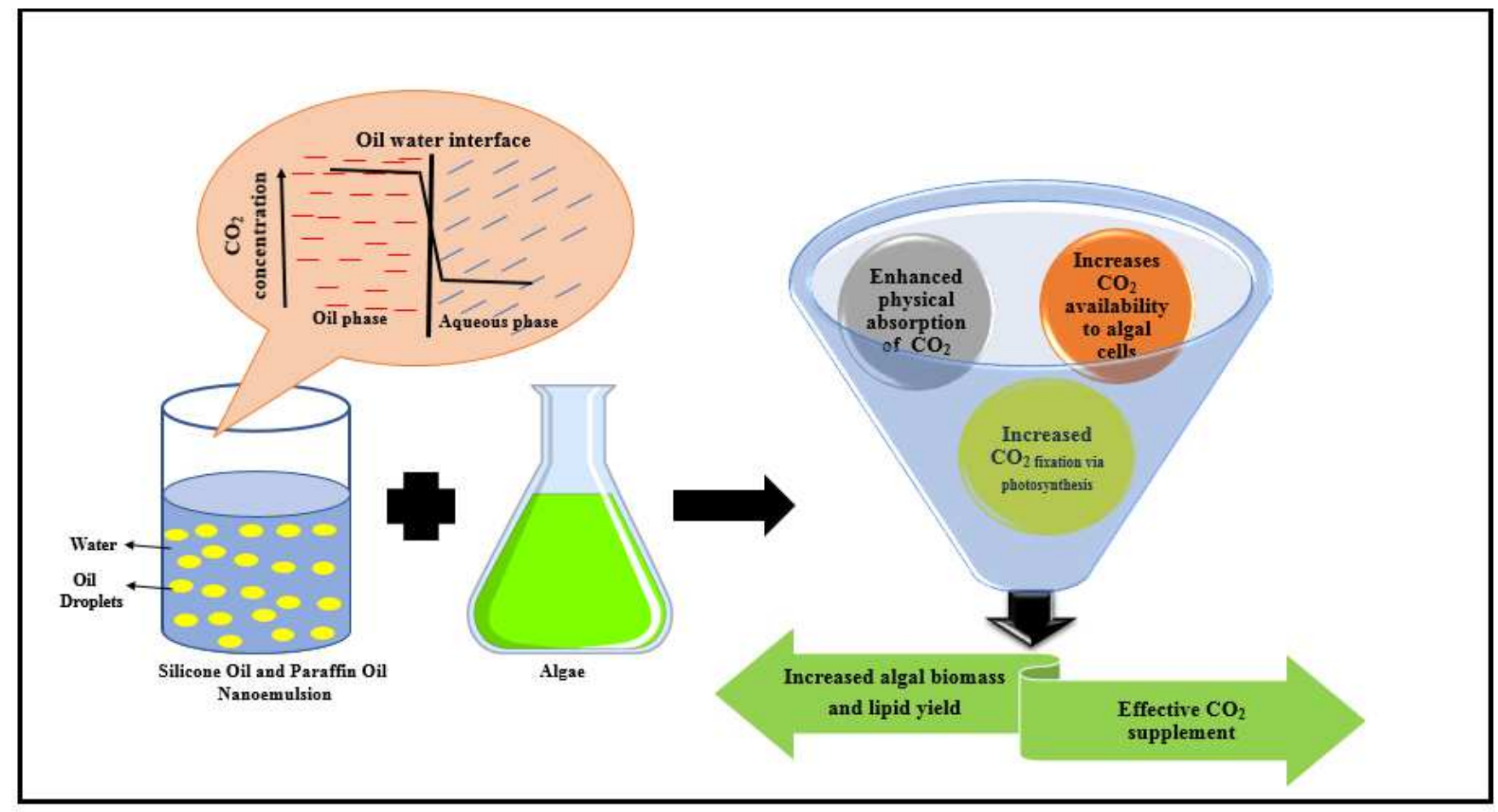




\section{Abstract}

Background: Microalgae are well-established feedstocks for applications ranging from biofuels to valuable pigments and therapeutic proteins. However, the low biomass productivity using commercially available growth mediums is a roadblock for its mass production. This work describes a strategy to boost the algal biomass productivity by using an effective $\mathrm{CO}_{2}$ supplement.

Results: In the present study, a novel nanoemulsion-based media has been tested for the growth of freshwater microalgae strain Chlorella pyrenoidosa. Two different nanoemulsion-based media were developed using $1 \%$ silicone oil nanoemulsion (1\% SE) and 1\% paraffin oil nanoemulsion (1\% PE) supplemented in BG11 media During 12-day growth experiment, the 1\% PE gave the highest biomass yield $\left(3.2 \pm 0.07 \mathrm{gL}^{-1}\right)$, followed by $1 \% \mathrm{SE}\left(2.75 \pm 0.07 \mathrm{gL}^{-1}\right)$ and control $\left(1.03 \pm 0.02 \mathrm{gL}^{-1}\right)$. The respective microalgal cell number measured using cell counter were $\left(3.0 \pm 0.21 \times 10^{6}\right.$ cells ml $\left.^{-1}\right),(2.4$

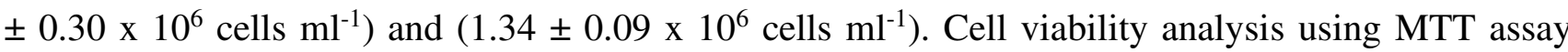
showed that $1 \% \mathrm{PE}$ also had higher viable cells (94\%) compared to 1\% SE (77\%) and control (53\%). The effective $\mathrm{CO}_{2}$ absorption tendency of the emulsion was highlighted as the key mechanism for greater biomass production. On the biochemical characterization of the produced biomass, it was found that the nanoemulsion cultivated C. pyrenoidosa had increased lipid $(1 \% \mathrm{PE}=26.8 \%, 1 \%$ $\mathrm{SE}=23.6 \%)$ and carbohydrates $(1 \% \mathrm{PE}=17.2 \%, 1 \% \mathrm{SE}=18.9 \%)$ content compared to the control (lipid $=18.05 \%$, carbohydrates $=13.6 \%)$.

Conclusions: This study provides a novel nanoemulsion which acts as an effective $\mathrm{CO}_{2}$ supplement for microalgal growth media which increase the growth of microalgal cells. Importantly, nanoemulsions cultivated microalgal biomass possess increment in lipid and carbohydrate content. This approach also provides high microalgal biomass productivity without alteration of morphological characteristics like cell shape and cell size.

Keywords: Microalgae, Nanoemulsion, Paraffin oil, Silicone oil, Biomass 


\section{Background:}

21 One of the major challenges in algal cultivation is the limited supply of $\mathrm{CO}_{2}$ from the atmosphere

22 to the cultivation system due to poor $\mathrm{CO}_{2}$ transfer rate from air to water (1). Finding suggests

23 that the diffusion of $\mathrm{CO}_{2}$ from the atmosphere to water cannot meet the photosynthetic efficiency

24 of algae (2). In this regard, most of the research has been focused on the delivery of $\mathrm{CO}_{2}$ to

25 photobioreactors, raceways, and ponds directly using air pumps, but this approach has two main

26 limitations. Firstly, the delivery of $\mathrm{CO}_{2}$ in such a manner is an energy-intensive process (3), and

27 secondly, most of the $\mathrm{CO}_{2}$ escape in the surroundings leading to its loss. To overcome these

28 limitations, chemical absorption of the carbon dioxide has been considered in the past, which

29 involves the addition of solvents like carbonates (4), amines (5), and piperazine (6). However,

30 these processes are energy-intensive and possess economic and technical limitations (7). In a

31 recent finding, solvent-based $\mathrm{CO}_{2}$ delivery was proposed which involves the capture of $\mathrm{CO}_{2}$ in

32 the solvent and its subsequent delivery to algal cells through the non-porous membrane e.g.

33 Polydimethylsiloxane (PDMS) membrane (8). This membrane-based system allows diffusion of

$34 \mathrm{CO}_{2}$ from solvent into algal cultivation media. However, with this approach, the cost of

35 membrane adds significant capital burden for large scale systems (9).

36 Therefore, an efficient $\mathrm{CO}_{2}$ delivery agent to the algal cultivation media is required which can be

37 used to increase the growth, productivity, and synthesis of biomolecules inside algal cells.

38 Moreover, the $\mathrm{CO}_{2}$ delivery agent should be cost-effective, non-toxic, and should have a high

39 affinity for $\mathrm{CO}_{2}$. Thus, the present study seeks to explore the two inert organic solvents named

40 silicone oil and paraffin oil in the form of oil-in-water nanoemulsion for the cultivation of algae. 
41 These inert organic solvents absorb $\mathrm{CO}_{2}$ through physical absorption without having any

42 chemical reaction. The binding responsible for physical absorption is being either Van der Waals

43 type or electrostatic between the $\mathrm{CO}_{2}$ and solvent molecules (10). The driving force responsible

44 for physical absorption is the high solubility of $\mathrm{CO}_{2}$ in the solvent.

45 To improve the physical absorption process, the concept of using nanoemulsion to capture $\mathrm{CO}_{2}$

46 has been proposed. Research literature suggests that the inert organic solvents like

47 perfluorodecalin (11), are effective in delivering $\mathrm{CO}_{2}$ to algal cells. However, their formulation

48 in the form of nanoemulsion for the algal cultivation area is unexplored. The physiochemical

49 properties like nano-size, stability against gravitational separation, easy handling (12) and, the

50 use of ingredients, which govern the functionality of the nanoemulsions, make it a suitable

51 choice for the absorption of $\mathrm{CO}_{2}$.

52 Hence, the present study focused on formulating oil-in-water nanoemulsion and its integration to

53 Chlorella pyrenoidosa cultivation (13). The aim was to develop an effective growth supplement

54 and study its effect on algal cell growth, morphology, pigment synthesis, biomass productivity,

55 and biomass composition. In the end, other possible mechanisms have been highlighted that

56 could have devoted to greater algal biomass production due to prepared nanoemulsions.

\section{2. MATERIALS AND METHODS:}

\subsection{Selection of oil and surfactant:}

59 Silicone, paraffin oil, and surfactant (Tween 80) were procured from Central Drug House (New 60 Delhi, India). Silicone oil is a nonpolar solute, having a kinematic viscosity of 300cS and has 61 efficient gaseous absorption capacity which makes it suitable oil for our experiment. Paraffin oil 
62 is a mixture of $\mathrm{C}_{10}-\mathrm{C}_{15}$ alkanes and cycloalkanes which are colorless, antioxidative, and have

63 low viscosity.

64 The nonionic surfactant Tween 80 (Polyoxyethylene (20) sorbitan monooleate) with HLB of 18,

65 was used for the formulation of silicone and paraffin oil nanoemulsion. The surfactant action is

66 to reduce the interfacial tension (IFT) between two phases (14).

67

68

69

70

71

72

73

74

75

76

77

78

79

80

81

82

\subsection{Formulation of Nanoemulsion}

The silicone and paraffin oil-in-water nanoemulsions were prepared by a high energy method (13). Nanoemulsion was formulated by adding an aqueous phase in a mixture of oil and surfactant. The resulting mixture was homogenized at $10,000 \mathrm{rpm}$ for $\sim 15$ minutes at $25^{\circ} \mathrm{C}(\mathrm{OV} 5$, VELP Scientifica, Italy) and the nanoemulsion was subjected to ultrasonic emulsification by using $20 \mathrm{kHz}$ EI-1000UP ultrasonicator (Electrosonic Industries, India) using 15mm titanium probe; the sonicator having sequential cycles of $45 \mathrm{~min}$, with sequential on and off.

\subsection{Characterization and stability analysis of silicone and paraffin oil nanoemulsion}

\section{(Gravimetric method and Droplet size observation by Dynamic Light Scattering)}

The resultant nanoemulsion was visually observed, to analyze the change in physical appearance. Nearly $25 \mathrm{ml}$ of silicone and paraffin oil nanoemulsion kept undisturbed in an 80 $\mathrm{ml}$ beaker at $25^{\circ} \mathrm{C}$ were observed for sedimentation or creaming for 15 days. The average diameter of the droplet size of silicone and paraffin oil nanoemulsion was observed by Dynamic Light Scattering (DLS) by photon associated spectrometer Malvern 4700 zeta-sizer (Anton Paar, Austria) equipped with an argon laser at a wavelength of $488 \mathrm{~nm}$. The temperature of the nanoemulsions was maintained at $25^{\circ} \mathrm{C}$ and the scattering angle was fixed at $90^{\circ}$. The samples 
83 were withdrawn at the $0^{\text {th }}$ day and $15^{\text {th }}$ day and observed for DLS study. The determination of

84 the droplet size of silicone oil and paraffin oil nanoemulsions was carried out by diluting $1 \mathrm{ml}$ of

85 the sample with $10 \mathrm{ml}$ of water to avoid multiple scattering.

\subsection{Dissolved $\mathrm{CO}_{2}$ analysis by titrimetric method}

87 The dissolved $\mathrm{CO}_{2}$ concentration (DCC) in the sample was determined by APHA (15). The

88

89

90

91

92

93 sample was titrated with $\mathrm{NaOH}$ solution $(0.01 \mathrm{~N})$ using phenolphthalein as an indicator. The colorless phenolphthalein indicator was used to recognize the endpoint of the reaction. All titrations were performed at room temperature and proper stirred condition and volume of $\mathrm{NaOH}$ was recorded. The dissolved $\mathrm{CO}_{2}$ concentration was determined by the mentioned formula.

$$
\mathrm{CO}_{2}\left(\mathrm{mgL}^{-1}\right)=[\text { Volume of } \mathrm{NaOH} \times \text { Conc. of } \mathrm{NaOH} \text { (in Normality) } \times 22 \times 1000]
$$

Volume of the sample

\subsection{Selection of algal strain and inoculum development:}

Pure culture of micro-algal species Chlorella pyrenoidosa was previously procured from the National Collection of Industrial Microorganisms (NCIM), NCL Pune (India). BG 11 broth of HiMedia M1541 was used as standard algal growth media. The algal culture was maintained in the algal growth chamber under LED light source $\sim 46.5$ to $50 \mu \mathrm{mol} \mathrm{m} \mathrm{m}^{-2} \mathrm{~s}^{-1}$ to provide the required photon flux density for photosynthesis of microalgal cultures with light and dark cycle of 12: 12 hours. The incubation temperature of microalgal cultivation was $25 \pm 1{ }^{\circ} \mathrm{C}$.

The inoculum of pure micro-algal strain C. pyrenoidosa was cultured in BG11 media using 250 $\mathrm{mL}$ Erlenmeyer flasks in controlled conditions (16). During the log phase of the growth cycle, 
$10330 \%$ of microalgal cell culture was used as inoculum for experimental units with an initial 104 absorbance of 2.0 at $680 \mathrm{~nm}$.

105

112 respectively.

\subsection{Experimental set -up}

The experiments were conducted in controlled conditions. The developed $100 \mathrm{ml}$ of silicone oil and paraffin oil nanoemulsion was mixed with $0.16 \mathrm{~g}$ BG11 growth media and inoculated with C. pyrenoidosa. The control was used for the respective set of experiments (C. pyrenoidosa in BG11 without silicone and paraffin oil nanoemulsion). The time duration of experiments was 12 days and performed in duplicates. The experimental flasks were incubated in continuous shaking mode $(\sim 150 \mathrm{rpm})$ at temperature $25 \pm 1{ }^{\circ} \mathrm{C}$ and light intensity $\sim 46.5$ to $50 \mu \mathrm{mol} \mathrm{m} \mathrm{m}^{-1}$

respectively.

113 The growth of $C$. pyrenoidosa was observed by measuring optical density at 680nm, chlorophyll114 a estimation and $\mathrm{pH}$ change at a regular interval of 48 hours. Additionally, the viability testing of 115 micro-algal cells was performed via MTT and SYTOX green staining on the $8^{\text {th }}$ day of the 116 experiment. Further, the harvested microalgal biomass was characterized by FESEM and FTIR 117 after the $12^{\text {th }}$ day.

\subsection{Analytical Techniques}

\section{Micro-algal growth in formulated nanoemulsion}

120 The optical density of $C$. pyrenoidosa was measured at $680 \mathrm{~nm}$ by using U.V-Vis

121 spectrophotometer (Lambda 35, Perkin Elmer, USA). The aliquots of the 2-ml algal sample were 122 withdrawn from well-mixed microalgal culture from the experimental unit and centrifuged at 
$1233600 \mathrm{~g}$ for 5 minutes. The obtained pellets were washed three- four times by PBS buffer and 124 surfactant (Tween 80) to remove silicone and paraffin oil nanoemulsions. The resultant pellets 125 were resuspended in 2-ml distilled water and placed in the cuvette for observation.

126 The $\mathrm{pH}$ of microalgal cells cultivated in nanoemulsions was measured by $\mathrm{pH}$ meter (10BN, 127 Eutech, U.S) at a regular interval of 48 hours. Chlorophyll-a estimation was performed by the 128 method prescribed by Chinnasamy et al., 2010 (17). The $2 \mathrm{ml}$ of microalgal cell suspension was 129 collected in microcentrifuge tubes and centrifuged at $3600 \mathrm{~g}$ for $10 \mathrm{~min}$. The pellet formed was 130 resuspended in $2 \mathrm{ml}$ of methanol after decanting and placed in the water bath for chlorophyll 131 extraction at $60^{\circ} \mathrm{C}$ for $\sim 30$ minutes. The chlorophyll content in the supernatant was observed 132 spectrophotometrically at 750, 665.2 and $652 \mathrm{~nm}$, and then calculated by Porra's equation (18):

$$
\text { Chl a }\left(\mu \mathrm{g} \mathrm{ml}^{-1}\right)=16.29\left(\mathrm{~A}^{665.2}-\mathrm{A}^{750}\right)-8.54\left(\mathrm{~A}^{652}-\mathrm{A}^{750}\right)
$$

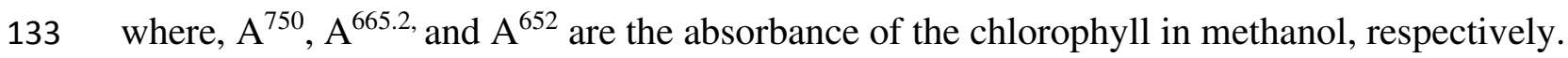

134 Samples of experiments were subjected to the determination of biomass growth (dry cell weight) 135 on the 13th day. The $50 \mathrm{ml}$ samples were centrifuged (R-8C, REMI, INDIA) at $3600 \mathrm{~g}$ for 10 136 min then decant the supernatant. The pellets were washed as mentioned previously. The 137 remaining pellets were suspended in distilled water (volume made upto $50 \mathrm{ml}$ ) and filtered with 138 pre-weighed Whatman filters. The filters with microalgal biomass were subjected to oven-dry at $13960^{\circ} \mathrm{C}$ for 24 hours and then cooled at room temperature in a desiccator and weighed (19). Dried 140 microalgal biomass was determined gravimetrically to evaluate the dry cell weight $\left(\mathrm{gL}^{-1}\right)(20)$. 141 Additionally, cell counting was performed by using cellometer (Catalog No. CHT4-PD100, 
142 Nexcelom Bioscience LLC). The data was noted, and averages of the duplicates were plotted in

143 the graph with standard deviation as error bar.

\section{2.8. Biochemical composition:}

145 After harvesting, the microalgal biomass was dried at $65-70^{\circ} \mathrm{C}$ for $48 \mathrm{hr}$ for biochemical 146 compositional analysis (till a constant mass is reached). Phenol-sulfuric acid was used for the 147 analysis of total carbohydrate content (21). Dried algal biomass (50mg) was hydrolyzed with $148 \quad 2.5 \mathrm{~N} \mathrm{HCl}(2.5 \mathrm{ml})$ and placed in a water bath for 3 hours at $100^{\circ} \mathrm{C}$, followed by cooling at room 149 temperature and neutralized with sodium carbonate. After neutralization, 0.1ml sample was 150 pipette out in a fresh tube and diluted to $1 \mathrm{ml}$. After dilution, $1 \mathrm{ml}$ phenol and $5 \mathrm{ml}$ sulfuric acid 151 were mixed and cooled in the water bath at $25-30^{\circ} \mathrm{C}$. The absorbance of the sample was 152 measured at 490nm and the total carbohydrate was calculated using the standard calibration 153 curve of glucose. Alkaline hydrolysis was performed, and total protein content was measured by 154 Folin-Lowery method (22).

155 Total lipid content was determined by modified Bligh and Dryer's method (23). The microalgal

156 cell wall was ruptured by heat treatment at $100-110^{\circ} \mathrm{C}$ up to 5 minutes for efficient extraction. 157 The chloroform-methanol mixture $(1: 1 \mathrm{v} / \mathrm{v})$ was added to the sample in the proportion of $1: 1$ and 158 lipid was estimated gravimetrically.

159 2.9. Viability testing of microalgal cells cultivated in silicone oil nanoemulsion and 160 microscopic analysis: 
161 To determine the viability of microalgal cells, 3-[4,5-dimethylthiazol-2-yl]-2,5162 diphenyltetrazoliumbromide (MTT) was performed. The $5 \mathrm{mg} \mathrm{ml}^{-1}$ of MTT dye was formed by 163 dissolving in Phosphate Saline Buffer (PBS). The PBS washed the microalgal pellets of $2 \mathrm{ml}$ 164 culture, followed by the addition of MTT dye (final concentration $0.5 \mathrm{mg} \mathrm{ml}^{-1}$ ) and incubate at $16537^{\circ} \mathrm{C}$ for 4 hours. After removal of MTT dye solution from microalgal cells, DMSO and 166 isopropanol (1:1) were added. The result was observed by taking absorbance at $570 \mathrm{~nm}$ and data 167 were expressed in the form of relative viability in percentage (24).

168 Relative viability $=($ Absorbance of treated cells $\div$ Absorbance of control $) \times 100$

169 Additionally, the viable cells were assessed by exposing the samples to nucleic acid stain

170 SYTOX green (Cat. No. S7020, Invitrogen). The Sytox stock solution of $50 \mu \mathrm{M}$ was prepared 171 and $5 \mu \mathrm{L}$ of stock solution was added to $95 \mu \mathrm{L}$ microalgal samples, resulting in a final dye 172 concentration of $5 \mu \mathrm{M}$ (25). Samples were incubated at room temperature in the dark for 30 173 min. The stained samples were loaded on a slide and placed into a fluorescence microscope 174 (Nikon Eclipse Ti-2 inverted microscope). The fluorescence of stained cells was observed at 175 100X magnification and images were captured using digital camera connected to the 176 microscope.

\section{2.10. Spectroscopic analysis by FTIR:}

178 The known volume of suspension was withdrawn and centrifuged at $3600 \mathrm{~g}$ for 10 minutes. The 179 pellets were washed 2-3 times with phosphate saline buffer (PBS) of $0.15 \mathrm{M}$ and placed for 180 lyophilization (Allied Frost FD3). The dried microalgal powder was ground and homogenized with 
$181 \mathrm{KBr}$ at the ratio of 1:100, and the mixture was pressed by a molding machine with a pressure

182 load of $200 \mathrm{~kg} \mathrm{~cm}^{-2}$ for 5 minutes. The fine $\mathrm{KBr}$ pellet was prepared and placed at Deuterated 183 triglycine sulfate (DTGS) detector of Nicolet Is50 (Thermo Scientific) FT-IR spectrometer (26).

184 The transmittance spectra were collected between $400 \mathrm{~cm}^{-1}$ to $4000 \mathrm{~cm}^{-1}$ with 64 scans.

185 2.11. Microscopic analysis:

186 Surface morphology and cell size were detected by Field Emission Scanning Electron Microscopy 187 (FESEM, JSM-7800F Prime, Jeol). The microalgal suspension was centrifuged at 3600g for 5- 10 188 minutes. The resultant pellet was washed 2-3 times with $0.15 \mathrm{M}$ phosphate saline buffer (pH 6.8). 189 After washing, the pellet was fixed using the fixative solution (2.5\% glutaraldehyde) for 30 minutes. 190 The resultant pellets were washed in phosphate saline buffer 3-4 times followed by serially 191 dehydrated with 25\%, 50\%, 75\%, 90\%, and 100\% ethanol, respectively. Finally, the fixed cells 192 were dried at room temperature and coated with Platinum (27).

\section{2.12. Statistical Analysis:}

194 All the experiments were performed in duplicates. The results presented here are mean of the 195 duplicates, mean \pm standard deviation, or mean with error bars in graphs unless mentioned 196 otherwise.

\section{3. RESULTS AND DISCUSSION:}

\subsection{Nanoemulsion Stability Analysis:}


199 The stability of nanoemulsion was observed in terms of their appearance and droplet size (28).

200 The samples were stored undisturbed for 15 days at $25^{\circ} \mathrm{C}$ for observation. On visual observation, 201 there was no creaming and flocculation in the nanoemulsion during the storage period. 202 Additionally, the stability of the nanoemulsions was evaluated by droplet size measurement. A 203 rapid increase in droplet size corresponds to that the stability of the nanoemulsion is low. Figure.

2041 displays the droplet size of $1 \% \mathrm{SE}$ and $1 \% \mathrm{PE}$ on the $0^{\text {th }}$ day and $15^{\text {th }}$ day, respectively. The 205 average droplet size observed in 1\% SE was in the range of $\sim 244 \mathrm{~nm}$ to $285 \mathrm{~nm}$ and $\sim 164 \mathrm{~nm}$ to $206297 \mathrm{~nm}$ in 1\% PE. As evident from Figure. 1, the size of the maximum droplets of nanoemulsions 207 were stable over a period of 15 days. The result indicated that the larger droplet size, greater than 208 a micron have been separated from the emulsion.

\section{3.3. Growth of Microalgae in Nanoemulsions:}

210 In the present study, $1 \% \mathrm{SE}$ and $1 \% \mathrm{PE}$ were prepared to test its potential in microalgal 211 cultivation. The microalgal cell growth in formulated nanoemulsions were evaluated by the 212 following parameters: optical density at $680 \mathrm{~nm}, \mathrm{pH}$, chl-a, biomass yield, and cell count.

213 Interestingly, for both the nanoemulsions, $C$. pyrenoidosa showed an increase in growth 214 compared with conventional BG11 media (control). Results obtained from measuring OD 680, 215 showed that $\sim 1.6$ folds growth was observed in $1 \%$ SE supplemented growth medium compared 216 with control on the $10^{\text {th }}$ day. On the other hand, 1\% PE growth medium gave an increment of 2171.8 folds in microalgal cell growth compared with control. In 1\% SE and 1\% PE supplemented 218 microalgal cultivation systems, the rapid exponential growth phase was observed from day-1 
219 compared with control. This exponential growth lasted till the $10^{\text {th }}$ day of the microalgal 220 cultivation in nanoemulsions while in control it lasted till the $8^{\text {th }}$ day.

221 Gonçalves et al., 2016 reported that the increased $\mathrm{CO}_{2}$ concentration in the microalgal 222 cultivation system prolonged the exponential phase (31). Araujo et al., 2005 observed via 223 cultivating diatom (Chaetoceros $c f$. wighamii) that the addition of carbon dioxide prolonged the 224 exponential phase and this phase of the life span of microalgae own highest nutritional value 225 which can be used as feed for aquatic animals $(32,33)$. In the proposed study, the growth pattern 226 including the duration of exponential phases was quite similar for both the nanoemulsions. The 227 microalgal cell growth during the exponential phase was much higher in nanoemulsion systems 228 compared with control (Figure. 2).

229 In our preliminary investigations, we observed DCC of 1\% SE, 1\% PE, and deionized water after 230 providing $5 \% \mathrm{CO}_{2}$ for $10 \mathrm{~min}$. This was the initial media in which experiments were carried out 231 with the addition of BG11 medium and algal inoculum. In this study, we observed that dissolved $232 \mathrm{CO}_{2}$ content was 1.6 times and 1.4 times higher in $1 \% \mathrm{SE}$ and $1 \% \mathrm{PE}$, respectively compared 233 with DI water. This experimental observation suggested that $1 \%$ SE and $1 \%$ PE were efficient in 234 the physical absorption of $\mathrm{CO}_{2}$ compared with deionized water.

235 It has been observed that the rise in $\mathrm{CO}_{2}$ is responsible for the rise in carboxylation activity of 236 ribulose 1,5 bisphosphate carboxylase/oxygenase (RuBisCo) and simultaneous suppression in 237 oxygenation activity, resulting in increased photosynthesis and cell growth (34). It has also been 238 seen that, under atmospheric $\mathrm{CO}_{2}$ concentration, the activity of RuBisCo is even less than half of 239 its catalytic capacity (35). Therefore, $\mathrm{CO}_{2}$ enrichment in the case of $1 \% \mathrm{SE}$ and $1 \% \mathrm{PE}$ might 240 have enhanced the RuBisCo activity which accelerated the microalgal cell growth. 
241 The decrease in microalgal growth in control was probably because of the reduction in the 242 amount of $\mathrm{CO}_{2}$ captured by the atmosphere compared with nanoemulsions. The higher carbon 243 dioxide content in nanoemulsions was supported by the $\mathrm{pH}$ measurement of nanoemulsions 244 substituted microalgal cultures. As shown in Figure.3, the change in $\mathrm{pH}$ observed in control $245(\sim 41 \%)$ was comparatively lower than the change in $\mathrm{pH}$ observed in $1 \% \mathrm{SE}(\sim 89 \%)$ and $1 \% \mathrm{PE}$ 246 ( $90 \%)$. The increase in $\mathrm{pH}$ was observed in cultivation with $1 \% \mathrm{PE}(\sim 5.4$ to 10.3$)$ and $1 \% \mathrm{SE}$ 247 ( 5.2 to 9.9) nanoemulsion, which was probably due to an increase in hydroxyl ion 248 concentrations during uptake of bicarbonates and $\mathrm{CO}_{3}{ }^{-2}$. In the case of $1 \% \mathrm{PE}$ substituted algal 249 cultivation, the $\mathrm{CO}_{3}{ }^{-2}$ could be the dominant species which probably increased the $\mathrm{pH}$ value 250 above 10. Since the $\mathrm{pH}$ change was higher, it suggests that more microalgal cells replicated 251 compared with control. It is because of the rise in $\mathrm{pH}$ corresponds to the algal growth (36). This 252 study suggested that the $1 \% \mathrm{SE}$ and $1 \% \mathrm{PE}$ act as suitable alkalescent culture media which was 253 appropriate for the growth of microalgae (37).

254 Furthermore, chlorophyll-a content of $C$. pyrenoidosa cultivated in two nanoemulsions and 255 control as a function of culture time was investigated. During chlorophyll analysis, it was found 256 that $1 \%$ SE and $1 \%$ PE enhanced chl-a pigment synthesis by $76 \%$ and $53 \%$ compared with 257 control (Figure. 2). The increase in chlorophyll concentrations in nanoemulsions could be due to 258 the sufficient availability of $\mathrm{CO}_{2}$ to the microalgal cells.

259 In addition to this, a slight decrease $(\sim 15 \%)$ in chl-a content was observed in microalgal cells of $2601 \%$ PE compared to $1 \%$ SE. This change is directly linked with the rise in $\mathrm{pH}$ during microalgal 261 cultivation. Increased $\mathrm{pH}$ results in the volatilization of ammonia (38). The volatilization of 262 ammonia affects the $\mathrm{N}$ metabolism of algal cells and creates nitrogen limiting conditions inside 263 algal cells. This impacts the chlorophyll content in microalgae (39). Literature also suggests that 
264 the increase in $\mathrm{CO}_{2}$ concentration leads to acidification of the algal cultivation system. This 265 results in the replacement of $\mathrm{Mg}^{+2}$ with $\mathrm{H}^{+}$and the formation of pheophytin instead of 266 chlorophyll (40). Salehi et al., 2019 studied the effect of n-alkane on Chlorella vulgaris and 267 reported that the existence of hydrocarbons in the medium increases the permeability of the cell 268 wall, resulting in the accumulation of hydrocarbons inside the algal cell (41). This might be the 269 reason for inconsistency between chlorophyll concentration and cell concentration in case of $1 \%$ 270 PE because n-alkanes are the major portion of paraffin oil.

271 Hence, overall it can be summarized that $1 \% \mathrm{SE}$ and $1 \% \mathrm{PE}$ nanoemulsions act as active $\mathrm{CO}_{2}$ 272 carriers which promote microalgal growth and chl-a synthesis comparative with conventional 273 growth media (BG11).

274 At the end of 12 days, the $C$. pyrenoidosa biomass obtained in both the nanoemulsions was 275 higher compared with control ( 1.03 $\left.\mathrm{g} \mathrm{L}^{-1}\right)$ (Figure.4). Also, the biomass yield of C. pyrenoidosa 276 was higher in $1 \%$ PE $\left(\sim 3.2 \mathrm{~g} \mathrm{~L}^{-1}\right)$ than $1 \% \mathrm{SE}\left(\sim 2.75 \mathrm{~g} \mathrm{~L}^{-1}\right)$. Table.2 highlights the biomass yield 277 of Chlorella species obtained using different growth media by various researchers. Out of these, 278 Wong, 2017 used five different media to grow Chlorella species and got maximum biomass 279 productivity (1.42 $\left.\mathrm{gL}^{-1}\right)$ using Bold Basal Media (42). In other such study, Prajapati et al., 2014 280 found the biomass productivity of $\left(0.98 \mathrm{gL}^{-1}\right)$ using Tap media (23). To efficiently deliver $\mathrm{CO}_{2}$ to 281 algal cells, Zheng et al. in 2016 used a membrane-based system and found an increase in biomass 282 productivity (43). The maximum biomass yield achieved was $1.77 \mathrm{gL}^{-1}$ with $\mathrm{CO}_{2}$ loading. 283 Interestingly, the biomass yield in $1 \% \mathrm{SE}$ and $1 \% \mathrm{PE}$ was higher compared to all the reported 284 studies so far, signifying the importance of this cultivation media.

285 The reason for this high productivity could be that the silicone and paraffin oil of nanoemulsions 286 acts as an organic phase in which carbon dioxide is absorbed physically and diffuse into the 
287 aqueous phase. A similar study was performed by Sawdon and Peng, 2014., using PFc emulsion

288 for the cultivation of C. vulgaris in tubular photobioreactor and observed increased in 289 microalgal cell concentration 4-folds, because of efficient $\mathrm{CO}_{2}$ delivery to microalgal cells by 290 PFc emulsion (44). Apart from this, silicone oil had also been studied in delivery of respiratory 291 gases $\left(\mathrm{CO}_{2}\right.$ and $\left.\mathrm{O}_{2}\right)$ in microbial cultivation (45), mammalian cell culturing (46) and in human 292 retinal treatment (47).

293 Additionally, the cell counting was performed for observing the microalgal cell population in $1 \%$ 294 SE, 1\% PE and control (Figure. 5). Cell counting was performed on the $12^{\text {th }}$ day of the 295 experiment using a cell counter. $1 \% \mathrm{PE}$ had the maximum cell number $\left(3.0 \pm 0.21 \times 10^{6} \mathrm{cells}^{-}\right.$

$\left.29{ }^{1}\right)$, followed by $1 \% \mathrm{SE}\left(2.4 \pm 0.30 \times 10^{6}\right.$ cells ml$\left.^{-1}\right)$ and control $\left(1.34 \pm 0.09 \times 10^{6}\right.$ cells ml $\left.^{-1}\right)$. The 297 cell number was in agreement with the cell growth and biomass yield obtained from 1\% PE and $2981 \%$ SE nanoemulsions. Hence, from the present study, it was concluded that the $1 \%$ SE and $1 \%$ 299 PE have successfully enhanced the potential of BG11 media by acting as an efficient $\mathrm{CO}_{2}$ 300 supplement for algal growth.

301 However, the dissolved $\mathrm{CO}_{2}$ concentration of $1 \% \mathrm{SE}$ was higher than the $1 \% \mathrm{PE}$ but the 302 microalgal growth, cell count and biomass yield obtained was higher in $1 \%$ PE supplemented 303 microalgal cultivation. This is due to the chemical composition of paraffin oil and most probable 304 explanations were highlighted in section 4.

\subsection{MTT, SYTOX Staining:}

306 The viability of cell indicates reproducibility of cells and also represent the physiological state 307 which involves the production of enzymes like oxidoreductase, etc. (48). To determine algal and 
308 cyanobacterial viability, tetrazolium compounds were introduced for viability assessment (49).

309 Lately, studies suggested that MTT (3-[4,5-dimethylthiazol-2-yl]-2,5-diphenyl tetrazolium

310 bromide) assay proved as a viable tool for viability assessment of algae and cyanobacteria.

311 Therefore, the study aims with the viability testing of microalgal cells grown in $1 \%$ SE and $1 \%$

312 PE emulsion on the 8th day of cultivation by MTT assay. Based on the growth curve, the $8^{\text {th }}$ day

313 was selected for MTT analysis as the microalgal culture started to move from the log phase to

314 the stationary phase during this period. The sensitivity of the MTT assay is based on the ability

315 of succinate dehydrogenase, microalgal mitochondrial enzyme, to convert MTT to a water-

316 insoluble formazan dye in viable cells. The formation of formazan dye is directly correlated to

317 cell viability and appears purple. The viability of cells is based on the intensity of purple color,

318 which shows that darker the color, the more the viability in cells (Figure. 8). In our case (Figure.

319 6), PE nanoemulsion gave the maximum cell viability (94\%), followed by SE (77\%) and control

320 (53\%). The results suggest that $1 \% \mathrm{PE}$ and $1 \% \mathrm{SE}$ nanoemulsions were non-toxic to the

321 microalgal cells. Further, using SYTOX Green and fluorescence microscopy, a clear distinction

322 between live and dead cells was observed. The observations confirmed that most of the 323 microalgal cells cultivated in 1\% SE and 1\% PE had intact chloroplasts and membranes

324 (Figure.7). Most of the cells emitted red autofluorescence and only few cells were stained by the 325 green fluorescent dye SYTOX Green. On the other hand, control culture gave large patches of 326 green emissions under a fluorescence microscope which confirmed the death stage of microalgal 327 cells in BG11. Healthy or viable cells were highly efficient in reproducibility which indirectly 328 increases cell density of microalgae. Therefore results suggest that microalgal cells cultivated in $3291 \%$ PE are more viable followed by $1 \%$ SE compared with control which was cross-examined by 
330

331

332

333

334

335

336

337

338

339

340

341

342

343

344

345

346

347

348

349

350

SYTOX, and obtained that live cells were higher in $1 \% \mathrm{PE}$ and $1 \%$ SE compared with control ( $\mathrm{i}$

e, Alg-1\% PE $>$ Alg-1\% SE> Control).

\subsection{Characterization}

\subsubsection{Bio-compositional analysis}

The bio-compositional analysis was performed to evaluate the quantitative changes in macromolecules (protein, lipids, and carbohydrates) of harvested microalgal biomass cultivated in $1 \%$ SE and $1 \%$ PE compared to control (Table:2).

It has been studied that as the stationary stage of cell growth comes, nutrient depletion condition occurs which results in a shift of carbon to storage compounds like carbohydrates and lipids (35). An elevated $\mathrm{CO}_{2}$ concentration in microalgal cells could trigger the Calvin cycle, resulting in the conversion of available $\mathrm{CO}_{2}$ into biomolecule syntheses like carbohydrates and lipids. The pathways for biosynthesis of lipids and carbohydrates compete for the same carbon source, with carbohydrate synthesis requiring less energy than lipids (35). The carbohydrate content of microalgal biomass recovered from $1 \% \mathrm{SE}$ and 1\% PE was $\sim 18.9 \%$ and $17.2 \%$ respectively, which was higher than control. Carbohydrates are the major synthetic products of carbon fixation metabolism. The finding suggests that an increase in the availability of $\mathrm{CO}_{2}$ to microalgal cells in cultivation media is the influencing factor of carbohydrate synthesis inside microalgal cells (50). Additionally, an increase in lipid content in algal biomass obtained from 1\% SE $(23.6 \% \pm$ $0.848)$ and $1 \% \mathrm{PE}(26.8 \% \pm 0.848)$ with respect to control $(18.05 \% \pm 0.353)$. Interestingly, in both the nanoemulsions, the highest lipid content was observed in microalgal biomass harvested from $1 \%$ PE. 
351 The protein content was slightly enhanced in $1 \%$ SE cultivated microalgal cells $(53.75 \% \pm$

352 0.0707) compared to control, indicating they can be used as aquaculture feedstock, which desires

353 protein content in the range of 35 to $60 \mathrm{wt} \%$ (51). The protein content of microalgal biomass

354 harvested from $1 \%$ PE ( 47\%) decreased compared with microalgal biomass of control ( $51 \%)$

355 and $1 \% \mathrm{SE}(\sim 53 \%)$. The high concentration of $\mathrm{CO}_{2}$ affects the $\mathrm{N}$ metabolism of algal cells

356 indirectly. As an outcome, the assimilation of nitrogen inside algal cells increases which create

357 nitrogen limiting condition (52). Therefore, the concentration of protein, as well as chlorophyll

358 decreases. This claim supports our experimental results obtained by $1 \%$ PE supplemented

359 microalgal cultivation.

360 However, efficient lipid and carbohydrate content obtained from microalgal biomass recovered

361 from nanoemulsions is a valuable property and may help in steady microalgal biomass

362 generation without changing operating conditions. The results revealed that $1 \% \mathrm{SE}$ and $1 \% \mathrm{PE}$

363 supplemented media are efficient in enhancing the synthesis of carbohydrate, protein, and lipid.

\section{$364 \quad 3.5 .2$. FTIR Analysis}

365 The microalgal samples were observed by using Fourier Transform Infrared (FTIR) technique

366 (Table:3). From last decades FTIR spectroscopy has proven a powerful tool in the study of the

367 biochemical composition of biological samples. The identification of peak is based on a 368 comparison of the bands of the recorded FTIR spectra of algae with reference literature (22). The

369 FTIR transmittance of the $C$. pyrenoidosa showed the presence of $\mathrm{Si}-\mathrm{O}, \mathrm{P}=\mathrm{O}, \mathrm{C}-\mathrm{OH},-\mathrm{CO}$, -

$370 \mathrm{COOH}$, functional groups (Figure. 9). IR spectra of $C$. pyrenoidosa showed higher intensity of

371 lipid and carbohydrates functional groups from algal biomass of $1 \% \mathrm{SE}$ and $1 \% \mathrm{PE}$. The strong

372 peak at1652-1653 $\mathrm{cm}^{-1}, 1266 \mathrm{~cm}^{-1}, 1089 \mathrm{~cm}^{-1}$ representing amide I, protein, and nucleic acid 
373 proteins were observed in microalgal biomass recovered from 1\% SE. It supports the result

374 obtained from biochemical characterization, suggesting biomass was rich in protein. The bands

375 at $1200-950 \mathrm{~cm}^{-1}$ have shown absorption strength in biomass of both i.e., $1 \%$ SE and $1 \%$ PE

376 which directs the presence of carbohydrate content compared to control. Two regions are

377 commonly used for the assessment of lipid content. One is at $1740 \mathrm{~cm}^{-1}$, conveying stretching of

378 the ester bond and other between $2800-3000 \mathrm{~cm}^{-1}$ having methyl and methylene group. The strong

379 absorption bands observed at 1456,1744, 2852, 2922, $2924 \mathrm{~cm}^{-1}$ clearly shows the presence of

380 membrane lipids and lipids representing $\mathrm{CH}_{2}, \mathrm{CH}_{3}, \mathrm{C}=\mathrm{O}$ groups in biomass obtained from $1 \%$

381 SE and 1\% PE compared with control. It was clearly visible from the FTIR spectra of

382 nanoemulsions recovered biomass of $C$. pyrenoidosa that distinct fingerprints of lipids,

383 carbohydrates, and proteins exist in the biomass. FTIR spectroscopy appears as a viable

384 analytical tool to evaluate the biofuel potential of algae.

385

386

387

388

389

390

391

392

393

\subsubsection{Microscopic Analysis:}

The $12^{\text {th }}$ day biomass of $C$. pyrenoidosa was subjected to FESEM analysis to investigate the morphological variation in the cell structure. Figure: 10 a-1, 10 a-2, and 10 a-3 show the FESEM images of $C$. pyrenoidosa grown in BG11, $1 \%$ SE, and $1 \%$ PE. From all the three figures, it was evident that the cells were spherical and packed together. The size of the microalgal cells in control was $6 \pm 2 \mu \mathrm{m}$ which was similar to the cell size in $1 \%$ SE and 1\% PE (Figure: 10 a-2 and 10 a-3). The microalgal cells in control possess a smooth cell surface, which indicated that cells were healthy. In the case of nanoemulsions, the cells grown kept their basic shape, but the edges of the cell wall were not similar to cells of control. Most of the cells in nanoemulsions were 
394 found in aggregation. The results showed that the cells had outer covering in both $1 \%$ SE and $1 \%$

395 PE. It might be due to the release of recalcitrant Extracellular polymeric substance (EPS) in the 396 case of nanoemulsion. The EPS is a sticky substance that algal cells release and is made of 397 organic components. The presence of enhanced $\mathrm{CO}_{2}$ in $1 \% \mathrm{SE}$ and $1 \% \mathrm{PE}$ nanoemulsions might 398 have triggered the microalgal cells to release this substance. It has been reported that the elevated $399 \mathrm{CO}_{2}$ concentration stimulates the metabolic carbon flux of algal cells and in order to maintain 400 carbon balance, algae excrete organics like EPS (53). Also, figure 10 a-2 and 10 a-3 suggest that 401 cells were morphologically intact with no cell damage, which indicates the good integrity of 402 algal cells.

\subsection{Other possible mechanisms for improved algal growth in nanoemulsions:}

404 It should be noted that the nanoemulsions used in the proposed study possess higher solubility of $405 \mathrm{CO}_{2}$ compared with conventional growth media. However, it was not obvious that the higher 406 solubility of $\mathrm{CO}_{2}$ was the only reason for increased microalgal growth in nanoemulsions 407 substituted algal growth media. Based on literature several other factors could have resulted in 408 greater microalgal biomass productivity in conjugation with nanoemulsions. Some of the 409 possible mechanisms are summarized as follows:

410 - In our preliminary investigations, a higher concentration of oil $(1 \%, 2 \%, 3 \%, 4 \%$, and $5 \%$ ) was used to observe the growth of $C$. pyrenoidosa. The high concentration of oil was supposed to enhance dissolved $\mathrm{CO}_{2}$ concentration in nanoemulsion, but microalgal cell concentration declined at a higher concentration of oil like 3\%, 4\%, 5\% (13). The results suggested that an increase in silicone oil concentration leads to a decrease in microalgal 
growth. Hence, the inference was that diminished microalgal cell growth was probably due to the scattering of light which reduces the depth penetration of light in the microalgal culture. Therefore, lower concentration was used for the cultivation of microalgae in the proposed study.

- Sawdon and Peng, 2014 has reported the use of perfluorocarbon (PFC) to improve algal photosynthesis by decreasing dissolved oxygen in a tubular photobioreactor (44). The mechanism proposed by the authors was the absorption of oxygen by the PFC suspended in the culture which was produced by the algal cells during photosynthesis. In the proposed study also, the organic compounds possess higher solubility of oxygen (54) compared to water or the conventional growth media. Therefore, these organic solvents (silicone and paraffin oil) might help to decrease oxygen content in the continuous phase cultivation systems.

- Earlier studies have been reported that nanosuspension can also enhance the mass transfer of solutes (55). In a quiescent fluid, diffusion is the main mechanism for mass transfer. For the case of nanosuspensions, in addition to diffusion, due to the Brownian motion of the suspended particles/droplets local disturbance velocity fields are also generated (56). The resultant microscale convection of the fluid can enhance the mass transfer rates of solutes in a suspension. In the present study also, the droplets of oil could be contributing to improved mass transfer of nutrients, dissolved gases, etc. from the bulk growth media to the algal cells. 
- Scattering and absorption of light by the suspended particles in a suspension reduces the availability of light in a media and can lower the rate of photochemical reactions (57). However, the nature of suspended particles is transparent and used in a small volume, we observed that the residence time of light inside the suspension can increase (manuscript under preparation). Both the oils used in the proposed work were used in a small volume and transparent, which suggests that the increase in the residence time of light inside nanoemulsions. This might improve the light availability in the nanoemulsions supplemented media and the microalgal cells can efficiently utilize light to carry out photosynthesis.

- Paraffin components were found as a stimulant for algal growth at lower concentrations $(58,59)$. In general, the lower carbon content oil phase can work as a source of carbon to the algal cells. This could be the possible reason for the phenomenal increase in microalgal growth in $1 \% \mathrm{PE}$ along with enhanced $\mathrm{CO}_{2}$ availability for microalgal growth.

\section{Conclusions:}

451 The present study proved that oil-in-water based colloidal system offers a possibility of 452 increasing microalgae production and volumetric productivity in batch systems without 453 compromising the microalgae cellular structure. A significant enhancement in pigment synthesis 454 (chl-a) and biomass was observed. Also, the substantial increase in lipid content was obtained 455 during nanoemulsion-based microalgal cultivation. The absorption of $\mathrm{CO}_{2}$ in emulsions is the 456 possible mechanism by which biomass productivity was increased. Moreover, the biomass 457 productivity achieved in the present study is excellent using Chlorella species in different 
458 nanoemulsions supplemented growth media. Therefore, 1\% SE and 1\% PE nanoemulsions are 459 projected as efficient support mediums that could significantly boost microalgal productivity.

460 This research gave us the option to explore various biocompatible oils for the mass cultivation of 461 algae. The next step would be to check the recyclability of the emulsion and testing it with actual 462 sources of $\mathrm{CO}_{2}$ such as flue gas. The integration of the engineering approach with biotechnology 463 might help in making the algal cultivation process more feasible at a large scale in the future.

\section{Abbreviations:}

$465 \mathrm{SE}=1 \%$ Silicone oil nanoemulsion; $\mathrm{PE}=1 \%$ Paraffin oil nanoemulsion; Alg-1\% SE = Algal cells 466 in 1\% Silicone oil nanoemulsion; Alg-1\% PE = Algal cells in 1\% Paraffin oil nanoemulsion; chl$467 \mathrm{a}=$ Chlorophyll-a; OD $680=$ Optical Density at 680nm, Deionized water $=$ DI, Dissolved $\mathrm{CO}_{2}$ 468 concentration $=\mathrm{DCC}$

469 Acknowledgments:

470 This research was financially supported by Indian Institute of Technology, Delhi. Dr. Arghya 471 Bhattacharya and Rahul Jain, CRDT, IIT Delhi are acknowledged for their assistance in the 472 preparation of manuscript.

\section{Authors' Contributions}

474 All authors contributed via scientific discussions during the work. H.N planned and performed 475 experiments, data analysis, and drafted the manuscript. A.M and V.S contributed to the design of 
476 the experiments, coordination of experiments, and drafted the manuscript. All authors read and

477 approved the final manuscript.

\section{$478 \quad$ Funding}

479 The proposed work was supported by Faculty Interdisciplinary Research Project (FIRP), IIT 480 Delhi.

\section{Availability of data and materials}

482 The datasets during the current study available from the corresponding author on reasonable 483 request.

484 Ethics approval and consent to participate

485 Not applicable.

\section{Consent for publication}

487 All authors approved the manuscript.

488 Competing interests

489 The authors declare that they have no competing interests

\section{Author details}

$491{ }^{1}$ Applied Microbiology Laboratory, Centre for Rural Development and Technology, Indian 492 Institute of Technology Delhi, Hauz Khas, 110016, India. 
$493{ }^{2}$ Department of Chemical Engineering, Indian Institute of Technology Delhi, Hauz Khas, New 494 Delhi 110016, India.

495

496 1. Moreira D, Pires JCM. Atmospheric CO2 capture by algae: Negative carbon dioxide

\section{REFERENCES:} emission path. Bioresour Technol. 2016;215(2016):371-9.

2. Duarte JH, Fanka LS, Costa JAV. Utilization of simulated flue gas containing CO2, SO2, NO and ash for Chlorella fusca cultivation. Bioresour Technol. 2016;214(x):159-65.

3. Zheng Q, Martin GJO, Kentish SE. Energy efficient transfer of carbon dioxide from flue gases to microalgal systems. Energy Environ Sci. 2016;9(3):1074-82.

4. Duan Y, Guo X, Yang J, Zhang M, Li Y. Nutrients recycle and the growth of Scenedesmus obliquus in synthetic wastewater under different sodium carbonate concentrations. R Soc Open Sci. 2020;7(1).

5. Rosa GM, Morais MG, Costa JAV. Fed-batch cultivation with CO2 and monoethanolamine: Influence on Chlorella fusca LEB 111 cultivation, carbon biofixation and biomolecules production. Bioresour Technol. 2019;273(November 2018):627-33.

6. Zhang Z, Chen F, Rezakazemi M, Zhang W, Lu C, Chang H, et al. Modeling of a CO2piperazine-membrane absorption system. Chem Eng Res Des. 2018;131:375-84.

7. Baena-Moreno FM, Rodríguez-Galán M, Vega F, Alonso-Fariñas B, Vilches Arenas LF, Navarrete B. Carbon capture and utilization technologies: a literature review and recent advances. Energy Sources, Part A Recover Util Environ Eff . 2019;41(12):1403-33. 
513 8. Zheng Q, Martin GJO, Wu Y, Kentish SE. The use of monoethanolamine and potassium

514 glycinate solvents for CO2 delivery to microalgae through a polymeric membrane system.

$515 \quad$ Biochem Eng J. 2017;128:126-33.

516 9. Zheng Q, Xu X, Martin GJO, Kentish SE. Critical review of strategies for CO2 delivery to 517 large-scale microalgae cultures. Chinese J Chem Eng. 2018;26(11):2219-28.

518 10. Shamiri A, Shafeeyan MS, Tee HC, Leo CY, Aroua MK, Aghamohammadi N. Absorption 519 of CO2 into aqueous mixtures of glycerol and monoethanolamine. J Nat Gas Sci Eng. $520 \quad 2016 ; 35: 605-13$.

521 11. Lawrence V. Dressler, Cranston, Alexander Chirkov, Lincoln. Method for producing $522 \quad$ algae in photobioreactor. US20090151241A1; 2008 Jun 12.

523 12. Akbas E, Soyler B, Oztop MH. Formation of capsaicin loaded nanoemulsions with high 524 pressure homogenization and ultrasonication. Lwt. 2018;96(May):266-73.

525 13. Vikram Singh, Harshita Nigam, Anushree Malik. "Method for sequestering carbon-di526 oxide by enhancing algal growth, and applications thereoff.” India; 2018.

527 14. Jeong M, Lee JW, Lee SJ, Kang YT. Mass transfer performance enhancement by 528 nanoemulsion absorbents during CO2absorption process. Int J Heat Mass Transf . $529 \quad 2017 ; 108: 680-90$.

530 15. Anshu Bala Yakub. Study of waste water quality of milk processing unit. Study waste $531 \quad$ water Qual milk Process unit its Util. 2010;17-42.

532 16. Brunale P, Santana H, Cereijo CR, Nascimento RC, Sabaini PS, Brasil BSAF, et al. 533 Microalgae cultivation in sugarcane vinasse: Selection, growth and biochemical 
characterization. Vol. 228, Bioresource Technology. 2016. p. 133-40.

535 17. Chinnasamy S, Bhatnagar A, Hunt RW, Das KC. Microalgae cultivation in a wastewater 536 dominated by carpet mill effluents for biofuel applications. Bioresour Technol. $537 \quad 2010 ; 101(9): 3097-105$.

538 18. Porra RJ, Thompson WA, Kriedemann PE. Determination of accurate extinction 539 coefficients and simultaneous equations for assaying chlorophylls a and b extracted with 540 four different solvents: verification of the concentration of chlorophyll standards by 541 542

19. Jena U, Vaidyanathan N, Chinnasamy S, Das KC. Evaluation of microalgae cultivation 544 545 546 547 548 549 21. Dubois M, Gilles KA, Hamilton JK, Rebers PA, Smith F. Colorimetric Method for Determination of Sugars and Related Substances. Anal Chem. 1956;28(3):350-6.

550 22. Fryer HJL, Davis GE, Manthorpe M, Varon S. Lowry protein assay using an automatic microtiter plate spectrophotometer. Anal Biochem. 1986;153(2):262-6.

552 23. Prajapati SK, Malik A, Vijay VK. Comparative evaluation of biomass production and 553 bioenergy generation potential of Chlorella spp. through anaerobic digestion. Appl 554 Energy. 2014;114:790-7. 
555 24. Omar HH, Al-Judaibiand A, El-Gendy A. Antimicrobial, antioxidant, anticancer activity and phytochemical analysis of the red alga, laurencia papillosa. Int J Pharmacol. 2018;14(4):572-83.

558

25. Eckersley E, Berger BW. An engineered polysaccharide lyase to combat harmful algal blooms. Biochem Eng J. 2018;132:225-32.

26. Meng Y, Yao C, Xue S, Yang H. Application of fourier transform infrared (FT-IR) spectroscopy in determination of microalgal compositions. Bioresour Technol. $2014 ; 151: 347-54$.

27. Dananjaya SHS, Godahewa GI, Jayasooriya RGPT, Lee J, De Zoysa M. Antimicrobial effects of chitosan silver nano composites (CAgNCs) on fish pathogenic Aliivibrio (Vibrio) salmonicida. Aquaculture. 2016;450:422-30.

28. Hu YT, Ting Y, Hu JY, Hsieh SC. Techniques and methods to study functional characteristics of emulsion systems. J Food Drug Anal. 2017;25(1):16-26.

29. Choi W, Kim G, Lee K. Influence of the CO 2 absorbent monoethanolamine on growth and carbon fixation by the green alga Scenedesmus sp. Bioresour Technol. 2012;120:2959.

30. Wolfbeis OS, Kovács B, Goswami K, Klainer SM. Fiber-Optic Fluorescence Carbon Dioxide Sensor for Environmental Monitoring. Mikrochim Acta. 1998;129(3--4):181-8.

31. Gonçalves AL, Rodrigues CM, Pires JCM, Simões M. The effect of increasing CO2 concentrations on its capture, biomass production and wastewater bioremediation by microalgae and cyanobacteria. Algal Res. 2016;14:127-36. 
576 32. Araújo SDC, Garcia VMT. Growth and biochemical composition of the diatom

577 Chaetoceros cf. wighamii brightwell under different temperature, salinity and carbon

578 dioxide levels. I. Protein, carbohydrates and lipids. Aquaculture. 2005;246(1-4):405-12.

579 33. Fábregas J, Otero A, Domínguez A, Patiño M. Growth rate of the microalga Tetraselmis

580 suecica changes the biochemical composition of Artemia species. Mar Biotechnol.

$581 \quad 2001 ; 3(3): 256-63$.

582 34. Ghosh A, Kiran B. Carbon Concentration in Algae: Reducing CO2 From Exhaust Gas.

583 Trends Biotechnol. 2017;35(9):806-8.

584 35. Varshney P, Beardall J, Bhattacharya S, Wangikar PP. Isolation and biochemical

585 characterisation of two thermophilic green algal species- Asterarcys quadricellulare and

586 Chlorella sorokiniana, which are tolerant to high levels of carbon dioxide and nitric oxide.

587 Algal Res. 2018;30(December 2017):28-37.

588 36. Gerardi MH, Lytle B. The Biology and Troubleshooting of Facultative Lagoons. Biol $589 \quad$ Troubl Fac Lagoons. 2015;1-226.

590 37. Price GD. Inorganic carbon transporters of the cyanobacterial $\mathrm{CO} 2$ concentrating 591 mechanism. Photosynth Res. 2011;109(1-3):47-57.

592 38. Kesaano M, Gardner RD, Moll K, Lauchnor E, Gerlach R, Peyton BM, et al. Dissolved 593 inorganic carbon enhanced growth, nutrient uptake, and lipid accumulation in wastewater 594 grown microalgal biofilms. Bioresour Technol. 2015;180:7-15.

595 39. Zhu S, Huang W, Xu J, Wang Z, Xu J, Yuan Z. Metabolic changes of starch and lipid 596 triggered by nitrogen starvation in the microalga Chlorella zofingiensis. Bioresour 
Technol. 2014;152:292-8.

598 40. Devi MP, Mohan SV. Bioresource Technology CO 2 supplementation to domestic $599 \quad$ wastewater enhances microalgae lipid accumulation under mixotrophic 600 601

602 41. Salehi M, Biria D, Shariati M, Farhadian M. Treatment of normal hydrocarbons 603 contaminated water by combined microalgae - Photocatalytic nanoparticles system. J 604 Environ Manage. 2019;243(November 2018):116-26.

605 42. Wong Y. Growth Medium Screening for Chlorella vulgaris Growth and Lipid Production. 606 J Aquac Mar Biol. 2017;6(1):1-10.

607 43. Zhang W, Bhubalan K, Decho AW, Dittrich M, Zhu T. Carbonate Precipitation through 608 Microbial Activities in Natural Environment, and Their Potential in Biotechnology: A 609 Review. 2016 ;4.

610 44. Sawdon A, Peng C. Internal deoxygenation of tubular photobioreactor for mass 611 production of microalgae by perfluorocarbon emulsions. J Chem Technol Biotechnol 612 2014;(April).

613 45. Ramsey WS, Tanenholtz PEE. Means for Stimulating Microbial Growth, US Patent 614 4,166,006. 1979;(19):3-8.

615 46. Schulz C, Vogel JH, Scharfenberg K. Influence of Pluronic F-68 on the Ultrafiltration of 616 Cell Culture Supernatants. Anim Cell Technol. 1997;373-8.

617 47. Inoue M, Iriyama A, Kadonosono K, Tamaki Y, Yanagi Y. Effects of perfluorocarbon 
liquids and silicone oil on human retinal pigment epithelial cells and retinal ganglion cells. Retina. 2009;29(5):677-81.

48. Li J, Song L. Applicability of the MTT assay for measuring viability of cyanobacteria and algae, specifically for Microcystis aeruginosa (Chroococcales, Cyanobacteria). Phycologia. 2007;46(5):593-9.

49. Markelova AG, Vladimirova MG, Kuptsova ES. A comparison of cytochemical methods for the rapid evaluation of microalgal viability. Russ J Plant Physiol. 2000;47(6):815-9.

50. Ji MK, Yun HS, Hwang JH, Salama ES, Jeon BH, Choi J. Effect of flue gas CO2 on the growth, carbohydrate and fatty acid composition of a green microalga Scenedesmus obliquus for biofuel production. Environ Technol (United Kingdom). 2017;38(16):208592.

51. Jones SW, Karpol A, Friedman S, Maru BT, Tracy BP. Recent advances in single cell protein use as a feed ingredient in aquaculture. Curr Opin Biotechnol. 2020;61:189-97.

52. Singh SK, Rahman A, Dixit K, Nath A, Sundaram S. Evaluation of promising algal strains for sustainable exploitation coupled with $\mathrm{CO} 2$ fixation. Environ Technol (United Kingdom). 2016;37(5):613-22.

53. Li W, Xu X, Fujibayashi M, Niu Q, Tanaka N, Nishimura O. Response of microalgae to elevated $\mathrm{CO} 2$ and temperature: impact of climate change on freshwater ecosystems. Environ Sci Pollut Res. 2016;23(19):19847-60.

54. Chavan A, Madhusudan. Oxygen Mass Transfer in Biological Treatment System in the Presence of Non-aqueous Phase Liquid. APCBEE Procedia. 2014;9(1969):54-8. 
639 55. Krishnamurthy S, Bhattacharya P, Phelan PE, Prasher RS. Enhanced mass transport in 640 nanofluids. Nano Lett. 2006;6(3):419-23.

641 56. Veilleux J, Coulombe S. A dispersion model of enhanced mass diffusion in nanofluids. $642 \quad$ Chem Eng Sci. 2011;66(11):2377-84.

643 57. Alfano OM, Cabrera MI, Cassano AE. Modeling of light scattering in photochemical 644 reactors. Chem Eng Sci. 1994;49(24):5327-46.

645 58. Jiang Z, Huang Y, Xu X, Liao Y, Shou L, Liu J, et al. Advance in the toxic effects of 646 petroleum water accommodated fraction on marine plankton. Acta Ecol Sin. $647 \quad 2010 ; 30(1): 8-15$.

648 59. Sciences L. Effects of Petroleum Oils and Their Paraffinic, Asphaltic , and Aromatic 649 Fractions on Photosynthesis and Respiration of Microalgae. 1990;16:8-16.

650 60. Khalili A, Najafpour GD, Amini G, Samkhaniyani F. Influence of nutrients and LED light 651 intensities on biomass production of microalgae Chlorella vulgaris. Biotechnol Bioprocess Eng. 2015;20(2):284-90. 

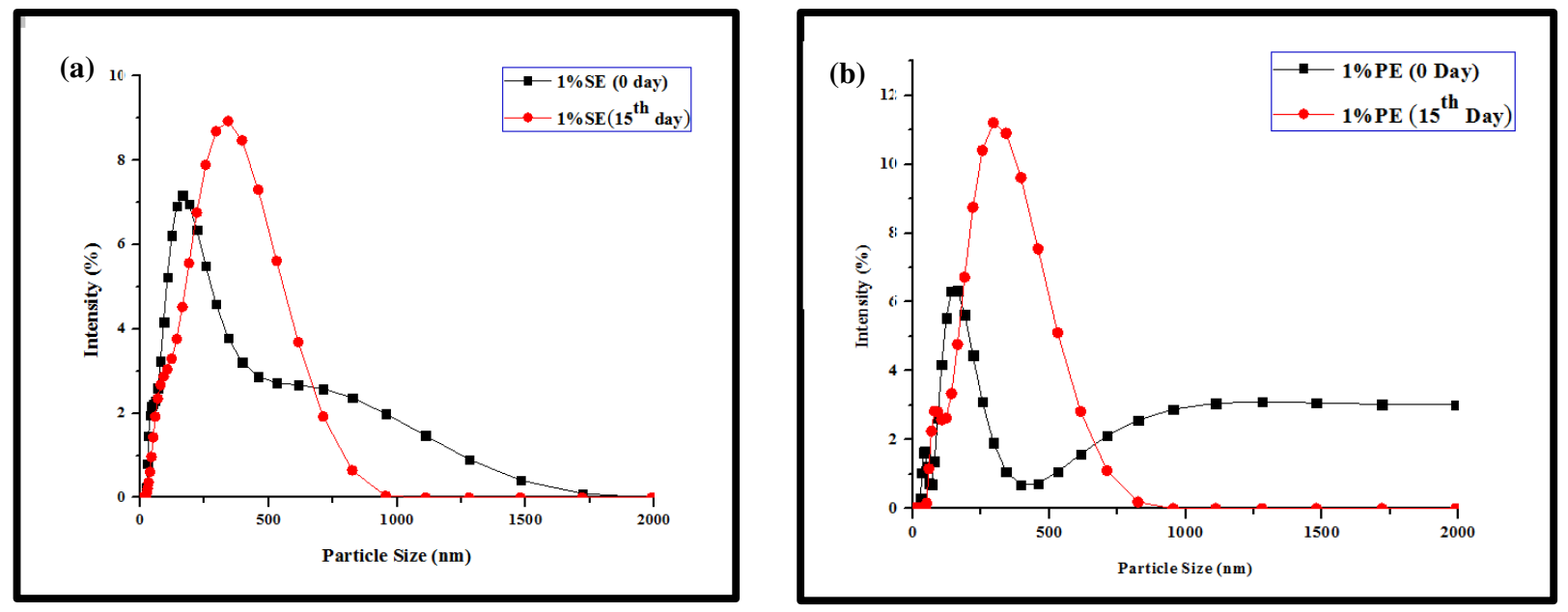

Figure 1: (a) DLS study of oil droplet size of $1 \%$ Silicone Oil Nanoemulsion $0^{\text {th }}$ day and $15^{\text {th }}$ day (b) DLS study of oil droplet size of $1 \%$ Paraffin oil nanoemulsion at $0^{\text {th }}$ day and $15^{\text {th }}$ day 


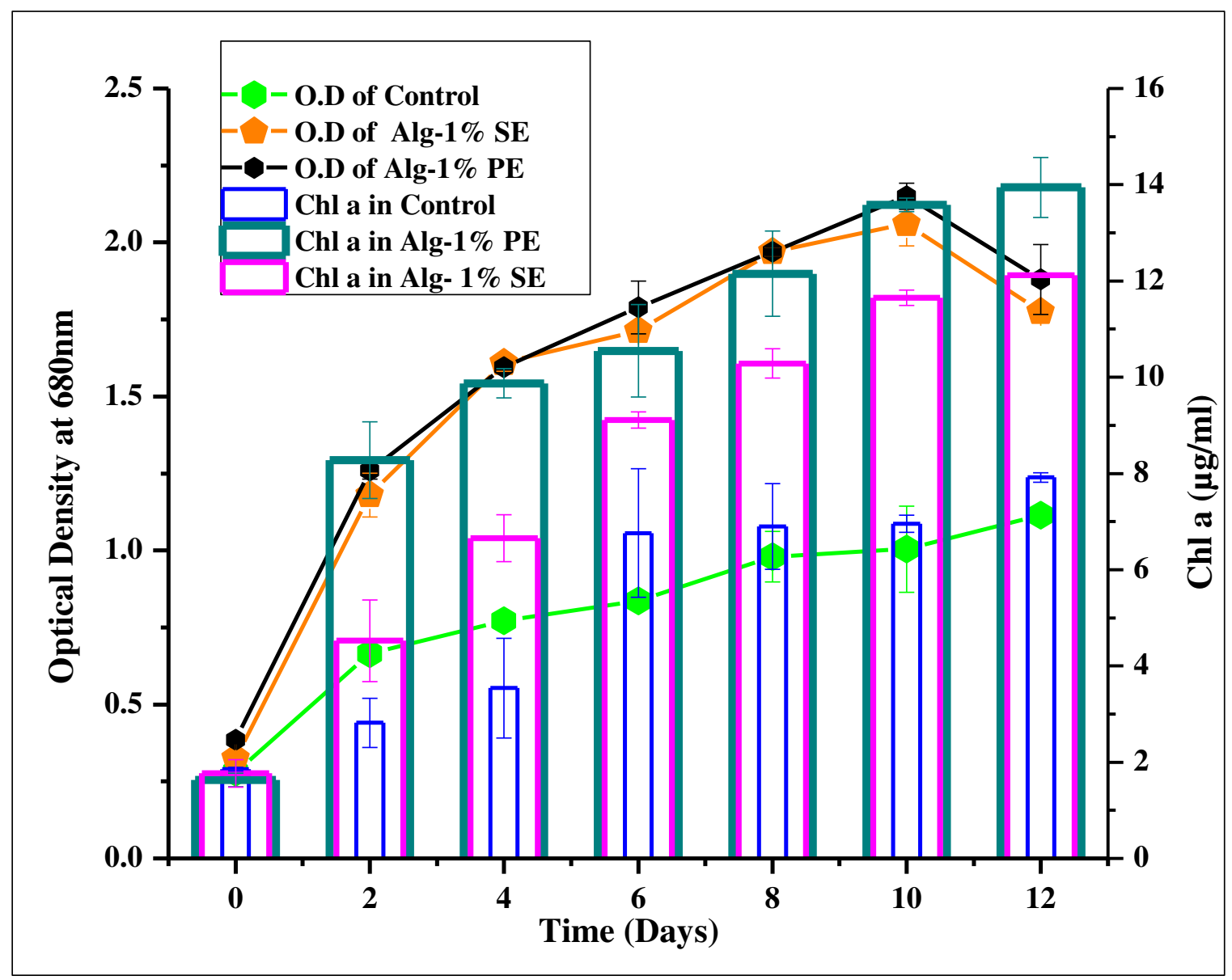

Figure 2: Growth profile of $C$. pyrenoidosa cultivated in 1\% SE and 1\% PE compared with control (BG11) in terms of OD 680 and Chl- a content. Errors bars are shown \pm SD. 


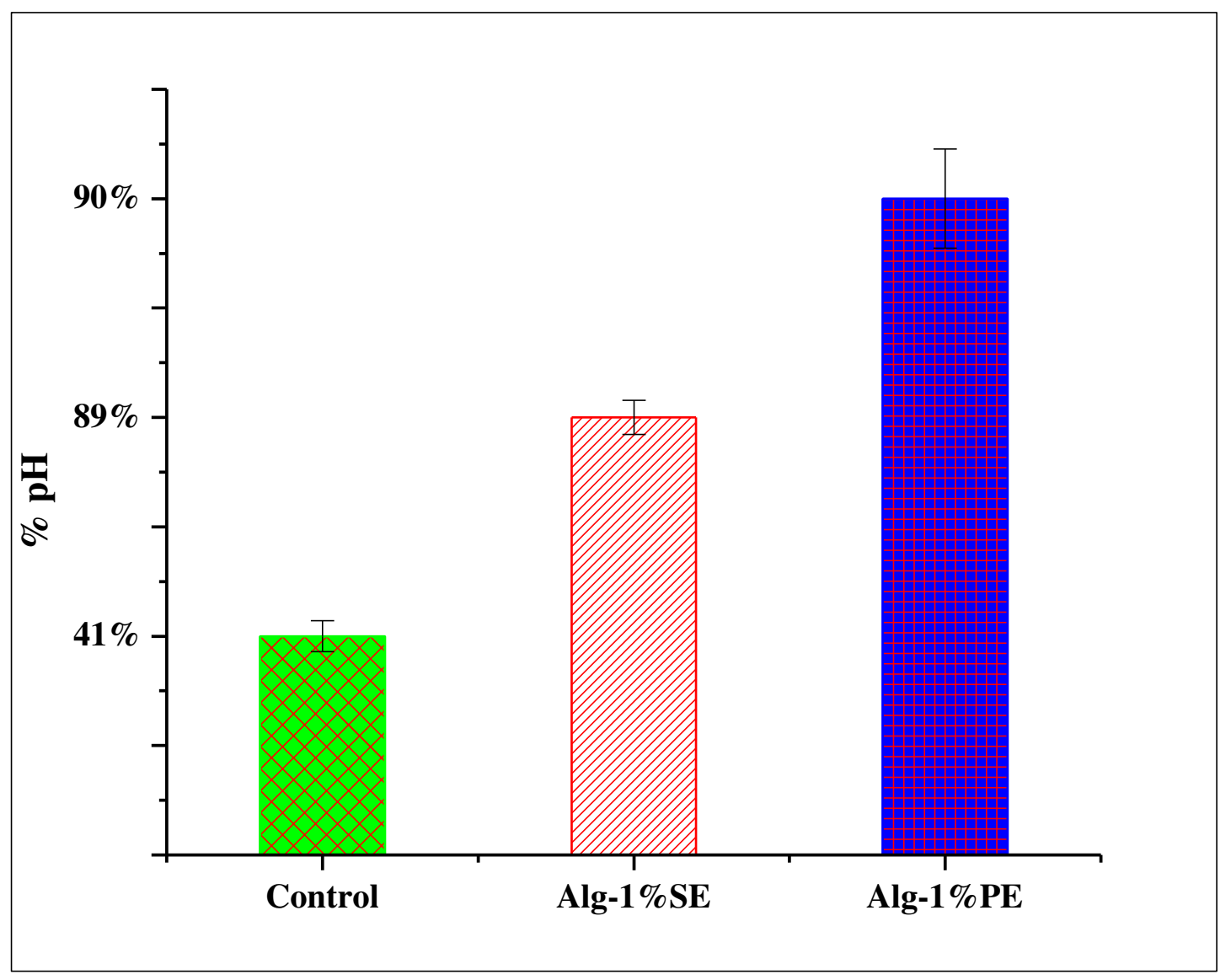

Figure 3: $\% \mathrm{pH}$ change observed during cultivation of $C$. pyrenoidosa in 1\% $\mathrm{SE}$ and $1 \% \mathrm{PE}$ compared with control (BG11). Errors bars are shown \pm SD. 


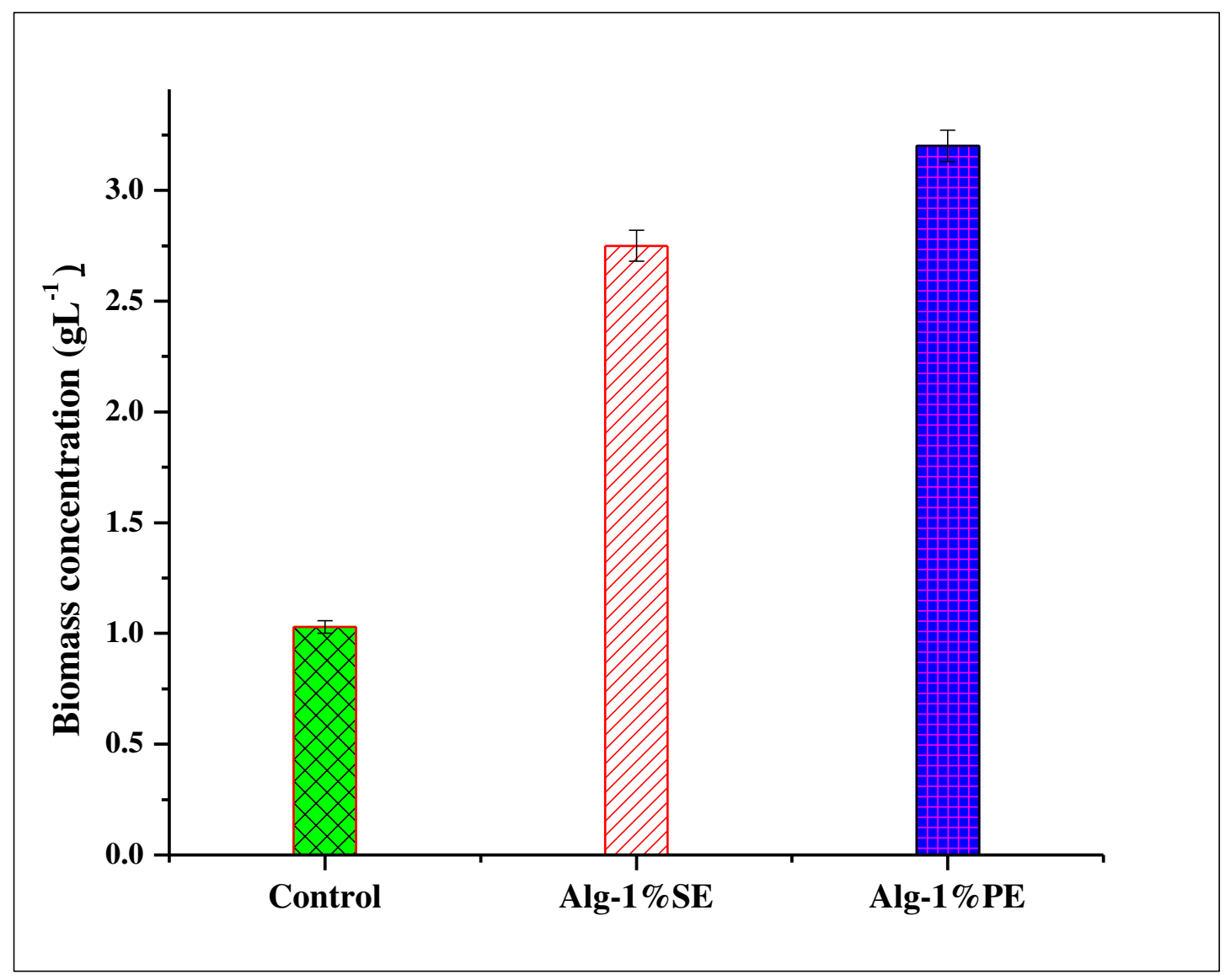

Figure 4: Comparison of biomass concentration of $C$. pyrenoidosa in $1 \% \mathrm{SE}$ and $1 \% \mathrm{PE}$ compared with control (BG11). Errors bars indicated are shown \pm SD. 


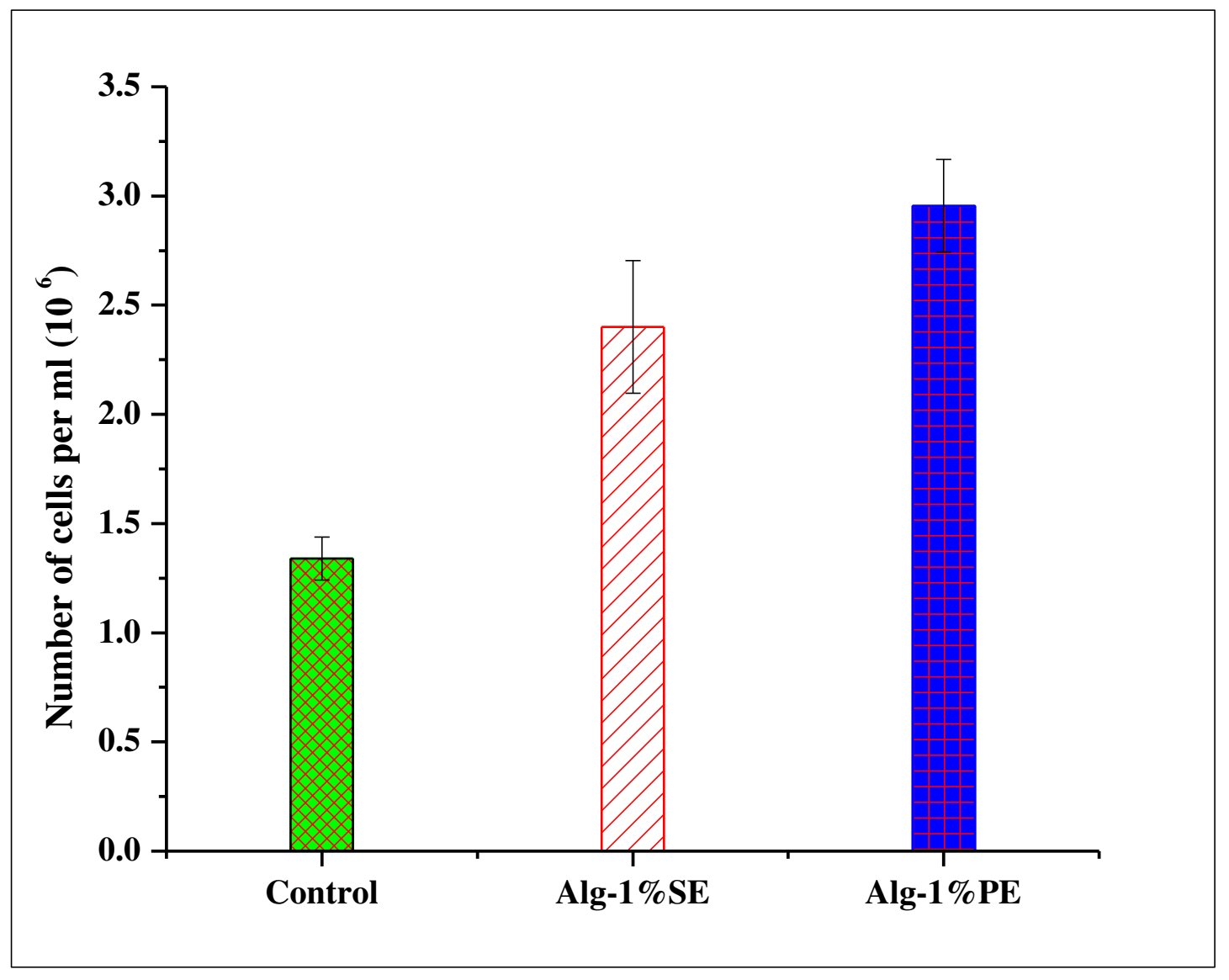

Figure 5: Cell count of $C$. pyrenoidosa cultivated in 1\% SE, 1\% PE and BG11(Control) on 12th day. Errors bars are shown \pm SD. 


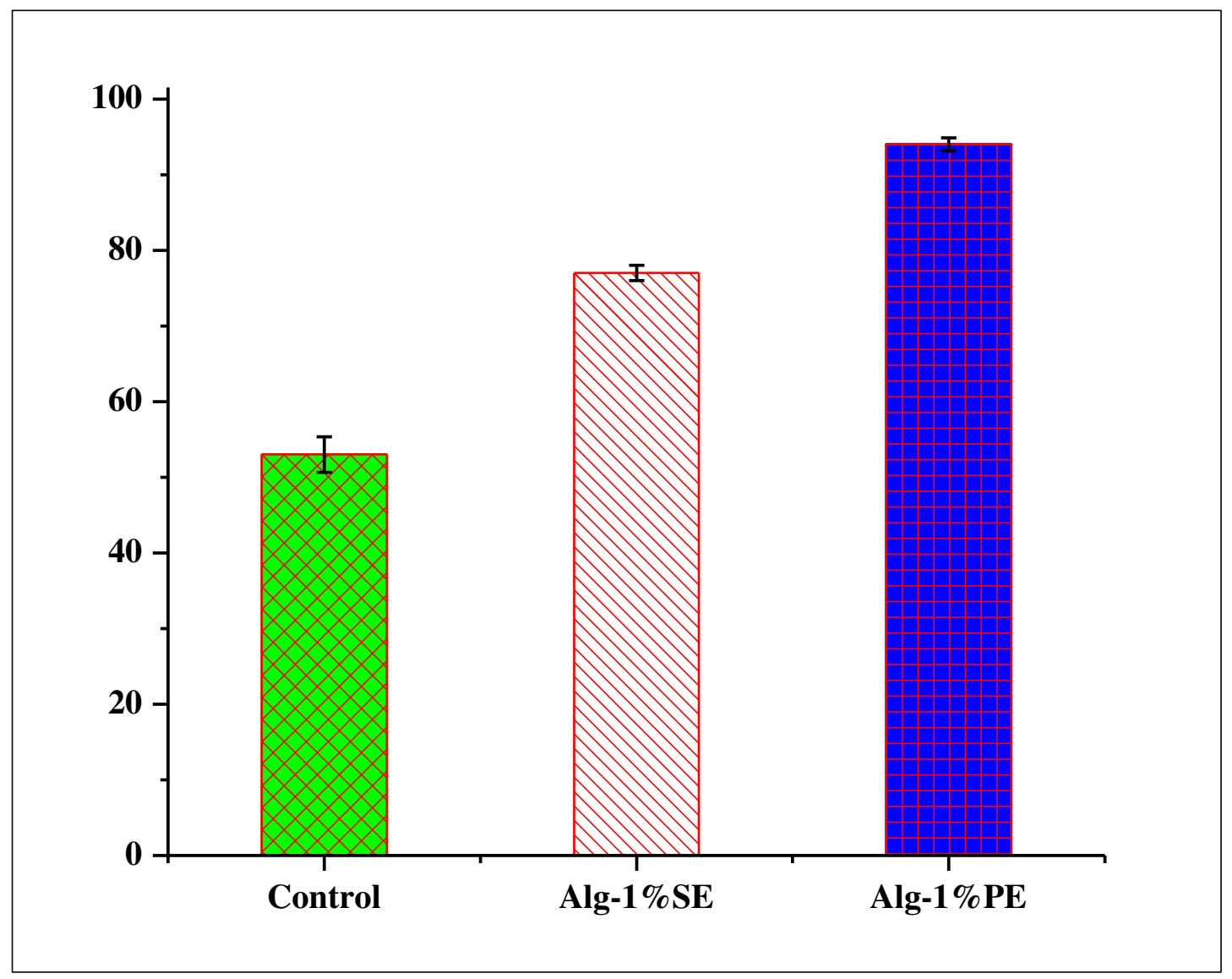

Figure 6: \% Cell viability observation of C. pyrenoidosa performed by MTT Assay in 1\% SE and $1 \% \mathrm{P}$ E. Errors bars are shown \pm SD in MTT analysis. 

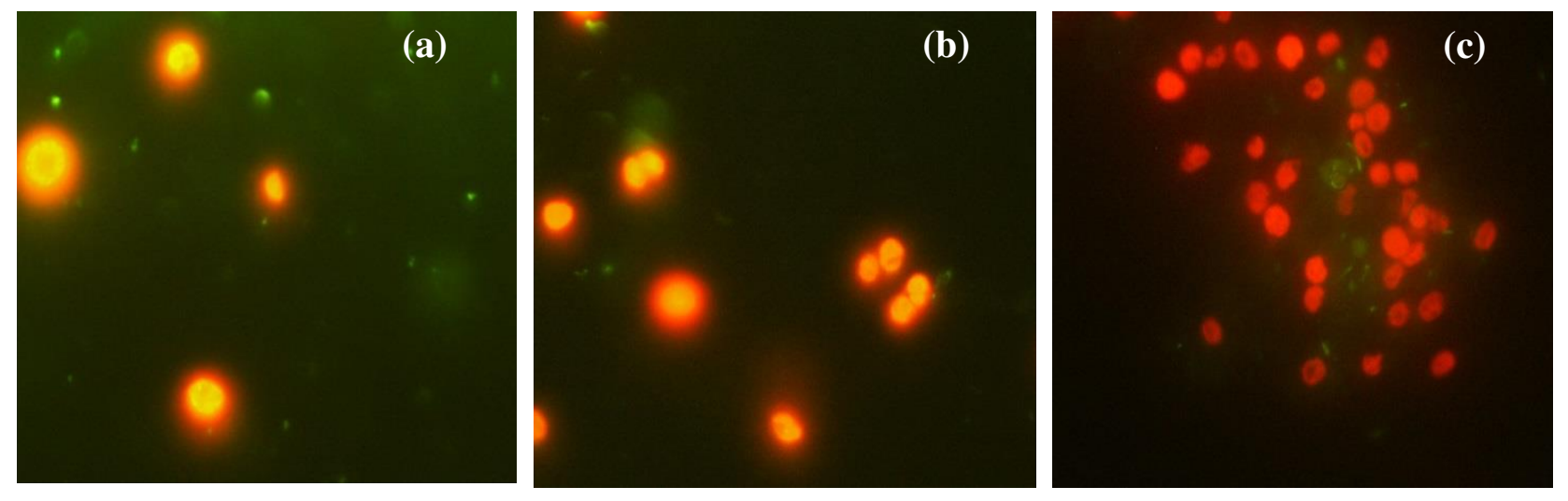

Figure 7: Live/dead discrimination of C. pyrenoidosa on $8^{\text {th }}$ day in (a) control. (b) $1 \%$ SE. (c) $1 \%$ PE. Live /dead discrimination of C. pyrenoidosa by SYTOX® Green staining. Live cells appear red (autofluorescence) while dead cells (SYTOX® Green stained) appear green or yellow color (scale bar: $100 \mu \mathrm{m}$ ). 


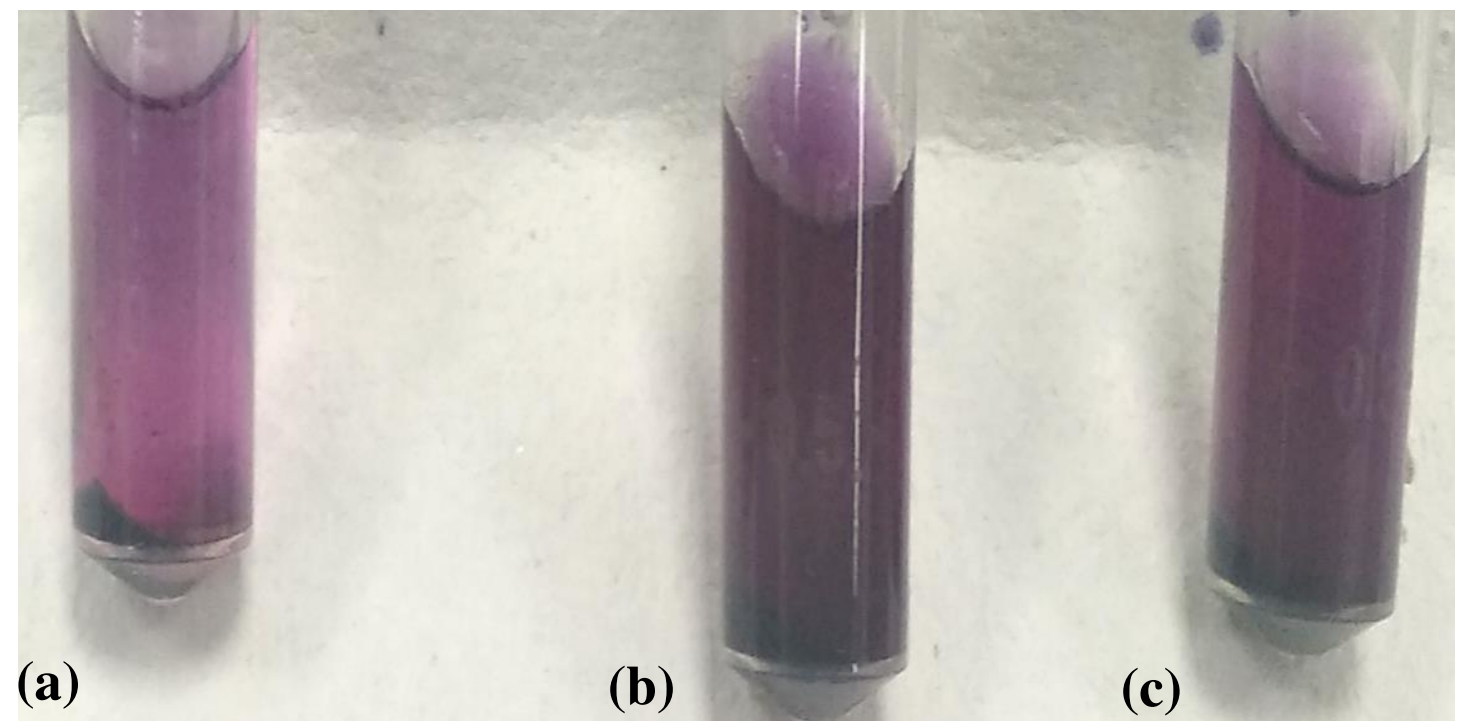

Figure 8: MTT cell viability assay of $C$. pyrenoidosa on $8^{\text {th }}$ day in (a) Control. (b) $1 \%$ PE. (c) $1 \% \mathrm{SE}$ 


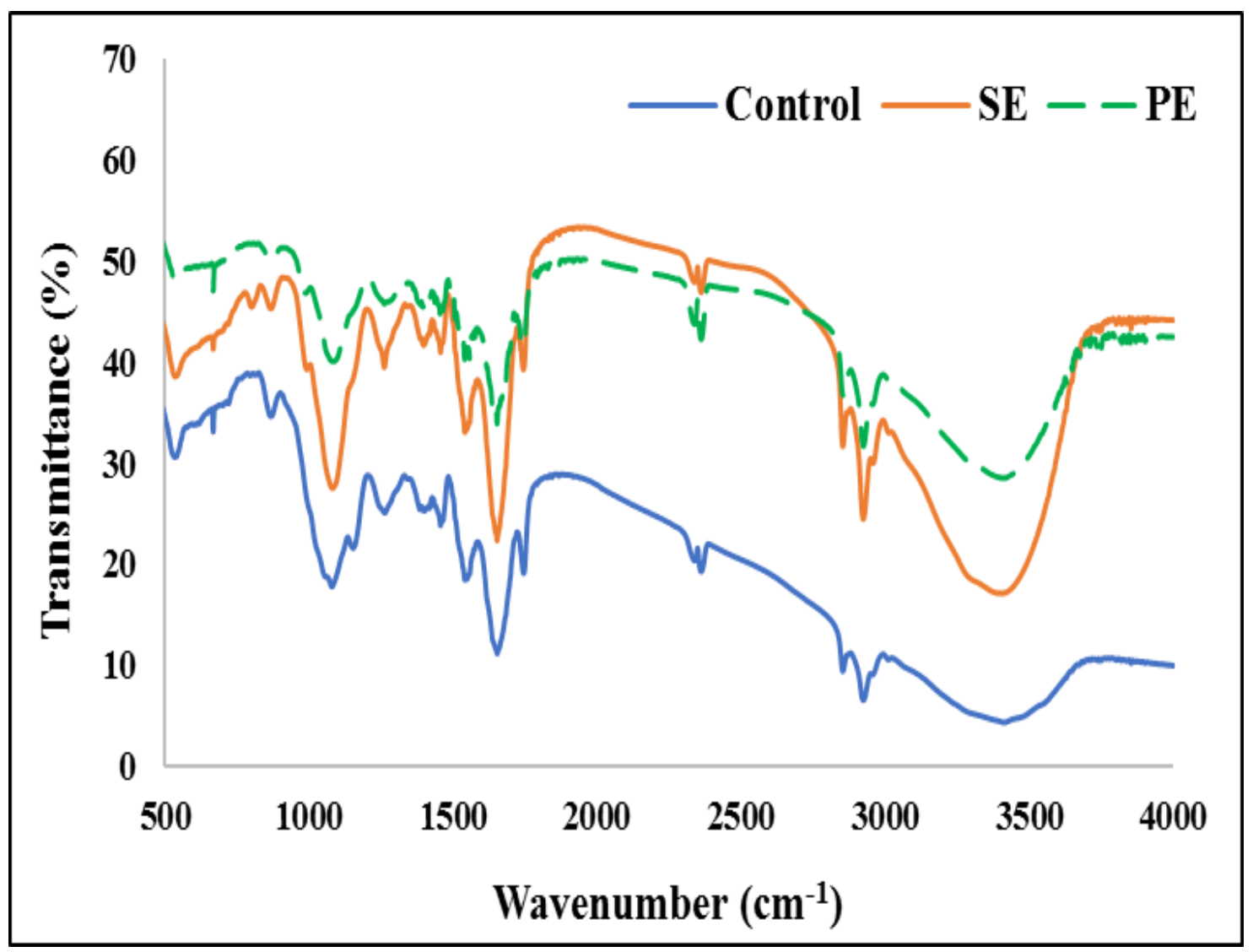

Figure 9: FTIR spectra of $C$. pyrenoidosa biomass cultivated in BG 11 (control), $1 \%$ SE and $1 \%$ PE. 

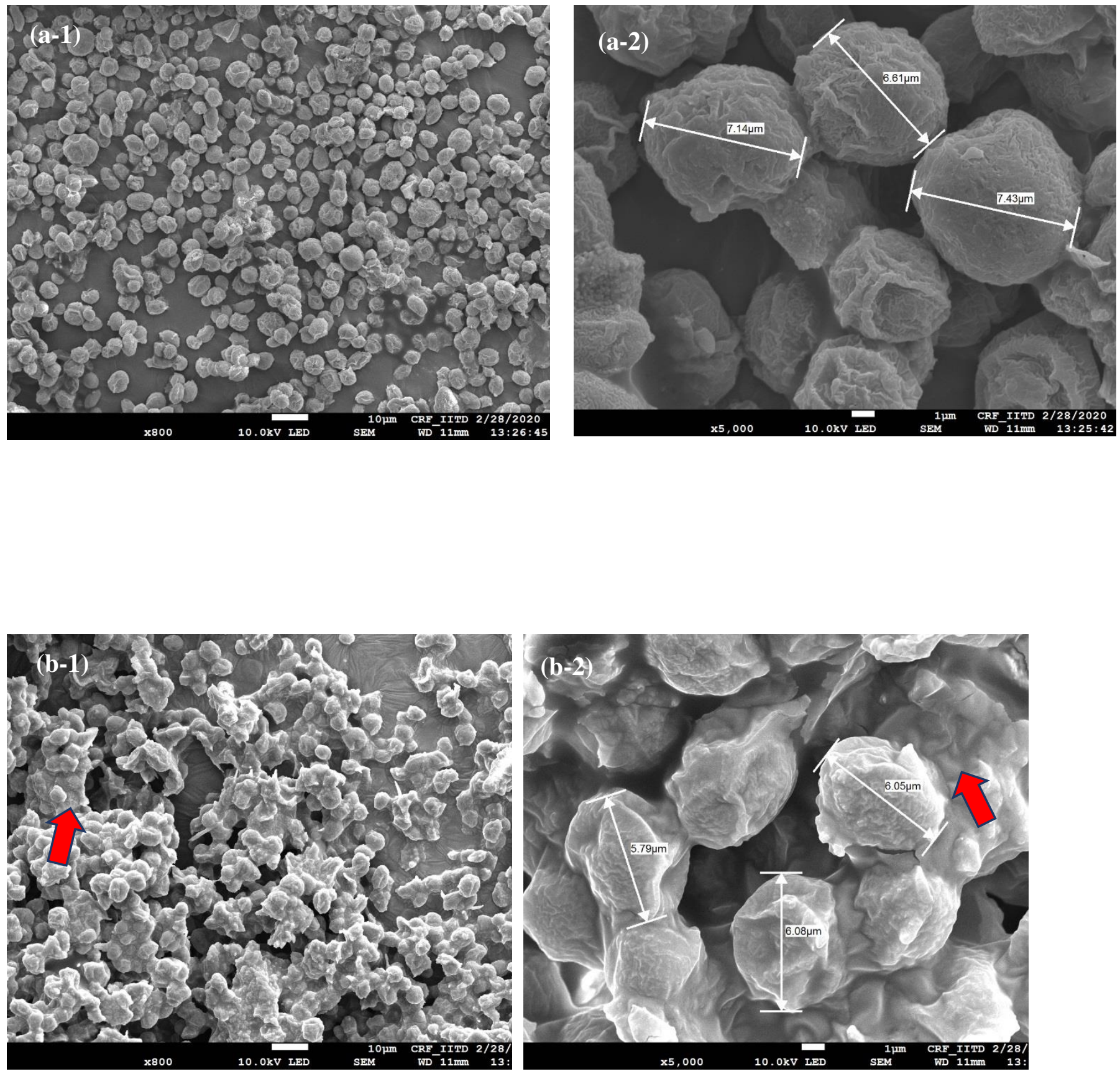

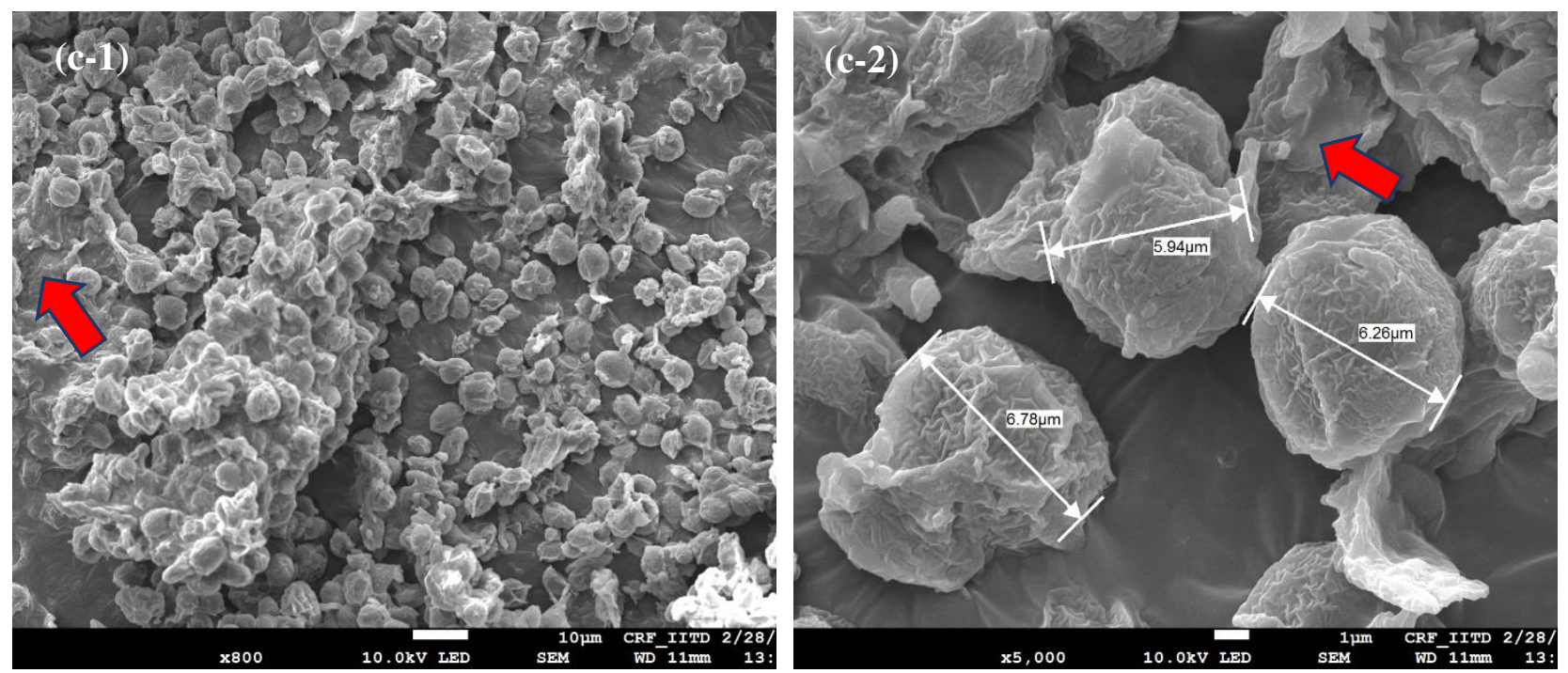

Figure 10. Field-emission scanning electron microscopy (FESEM) images of C. pyrenoidosa. (a-1) The image of cluster of cells of $C$. pyrenoidosa cultivated in BG11 i.e, control at 800x magnification; (a-2) The image of single cells of $C$. pyrenoidosa cultivated in BG11 i.e, control at 5000x magnification;( (b-1)The image of cluster of cells of $C$. pyrenoidosa grown in $1 \%$ Silicon oil emulsion (SE) at 800x magnification; (b-2)The image of single cells of $C$. pyrenoidosa grown in $1 \%$ Silicon oil emulsion (SE) at 5000x magnification; (c-1) The image of cluster of cells of $C$. pyrenoidosa grown in $1 \%$ Paraffin oil emulsion (PE) at 800x magnification;(c-2) The image of single cells of $C$. pyrenoidosa grown in $1 \%$ Paraffin oil emulsion (PE) at 5000x magnification. 
Table 1: Comparison of biomass yield of Chlorella sp.in different cultivation media

\begin{tabular}{|c|c|c|}
\hline Growth Medium & Biomass yield $\left(\mathbf{g L}^{-\mathbf{1}}\right)$ & References \\
\hline Bold Basal, Modified BG-11 & $1.42 \pm 0.012,0.9 \pm 0.01$ & $(42)$ \\
\hline $\begin{array}{c}\text { Carbonate Based Media at 0.5 } \\
\text { and 0.7 loading concentration }\end{array}$ & $1.63 \pm 0.10$ and $1.77 \pm 0.02$ & $(3)$ \\
\hline $\begin{array}{c}\text { Urea }+\mathrm{K}_{2} \mathrm{HPO}_{4}+ \\
\mathrm{MgSO}_{4} \cdot 7 \mathrm{H}_{2} \mathrm{O} \text { and Ammonium } \\
\text { ferric citrate }\end{array}$ & $1.37 \mathrm{~g} / \mathrm{L}$ & \\
\hline Tap-water & & $(60)$ \\
\hline $\begin{array}{c}1 \% \mathrm{SE} \text { and PE amended with } \\
\text { BG-11 }\end{array}$ & $2.75 \pm 0.07 \pm 0.11$ & $\mathrm{gL}^{-1}$ and $3.2 \pm$ \\
$0.07 \mathrm{gL}^{-1}$ & Proposed study \\
\hline
\end{tabular}

Table 2: Biomass (biochemical) composition of $C$. pyrenoidosa (represented as mean \pm SD).

\begin{tabular}{|c|c|c|c|}
\hline $\begin{array}{c}\text { Biochemical } \\
\text { composition }\end{array}$ & Control & SE & PE \\
\hline Carbohydrates & $13.6 \pm 0.565$ & $18.9 \pm 0.282$ & $17.2 \pm 0.565$ \\
\hline Proteins & $51.75 \pm 0.777$ & $53.75 \pm 0.0707$ & $47.1 \pm 0.141$ \\
\hline Lipids & $18.05 \pm 0.353$ & $23.6 \pm 0.848$ & $26.8 \pm 0.848$ \\
\hline
\end{tabular}


Table 3: Monitoring macromolecular changes in $C$. pyrenoidosa by FTIR analysis

\begin{tabular}{|c|c|c|c|}
\hline $\begin{array}{l}\text { Wavenumber } \\
\text { range }\left(\mathbf{c m}^{-1}\right)\end{array}$ & Assignments & Functional groups & Peak $\left(\mathrm{cm}^{-1}\right)$ \\
\hline $1064-880$ & $\begin{array}{ll}------ \\
\end{array}$ & Carbohydrate & 965 \\
\hline $1090-1030$ & $\begin{array}{l}\mathrm{P}=\mathrm{O} \text { or } \\
\mathrm{Si}-\mathrm{O}\end{array}$ & Nucleic acids & 1089 \\
\hline $1150-1000$ & $\mathrm{C}-\mathrm{O} / \mathrm{v} \mathrm{Si}-\mathrm{O}$ & $\begin{array}{c}\text { Polysaccharides/Siloxane } \\
\text { (Carbohydrate peak/siloxane } \\
\text { shoulder at } 1200 \mathrm{~cm}^{-1} \text { ) }\end{array}$ & 1072 \\
\hline 1263 & $\mathrm{C}-\mathrm{O}$ & Ester & 1260 \\
\hline 1275 & $\mathrm{C}-\mathrm{O}-\mathrm{H}$ & $\begin{array}{l}\text { Carbohydrates, proteins, } \\
\text { DNA, and RNA }\end{array}$ & 1266 \\
\hline $1398-1370$ & $\mathrm{CH}_{3}, \mathrm{CH}_{2}, \mathrm{C}-\mathrm{O}$ & Proteins, Carboxylic Groups & 1394 \\
\hline $1456-1450$ & $\mathrm{CH}_{2}, \mathrm{CH}_{3}$ & Lipid, Protein & 1456 \\
\hline $1550-1640$ & $\mathrm{~N}-\mathrm{H}$ bending & Amide & 1558 \\
\hline $1655-1638$ & $\mathrm{C}=\mathrm{O}$ & Protein (Amide I) & $1652-1653$ \\
\hline $1745-1734$ & $\mathrm{C}=\mathrm{O}$ of esters & Membrane Lipids, Fatty acids & 1744 \\
\hline $2875-2850$ & $\mathrm{CH}_{2}, \mathrm{CH} 3$ & Lipids & 2852 \\
\hline $2930-2920$ & $\mathrm{CH}_{2}$ & Lipids & 2922,2924 \\
\hline
\end{tabular}




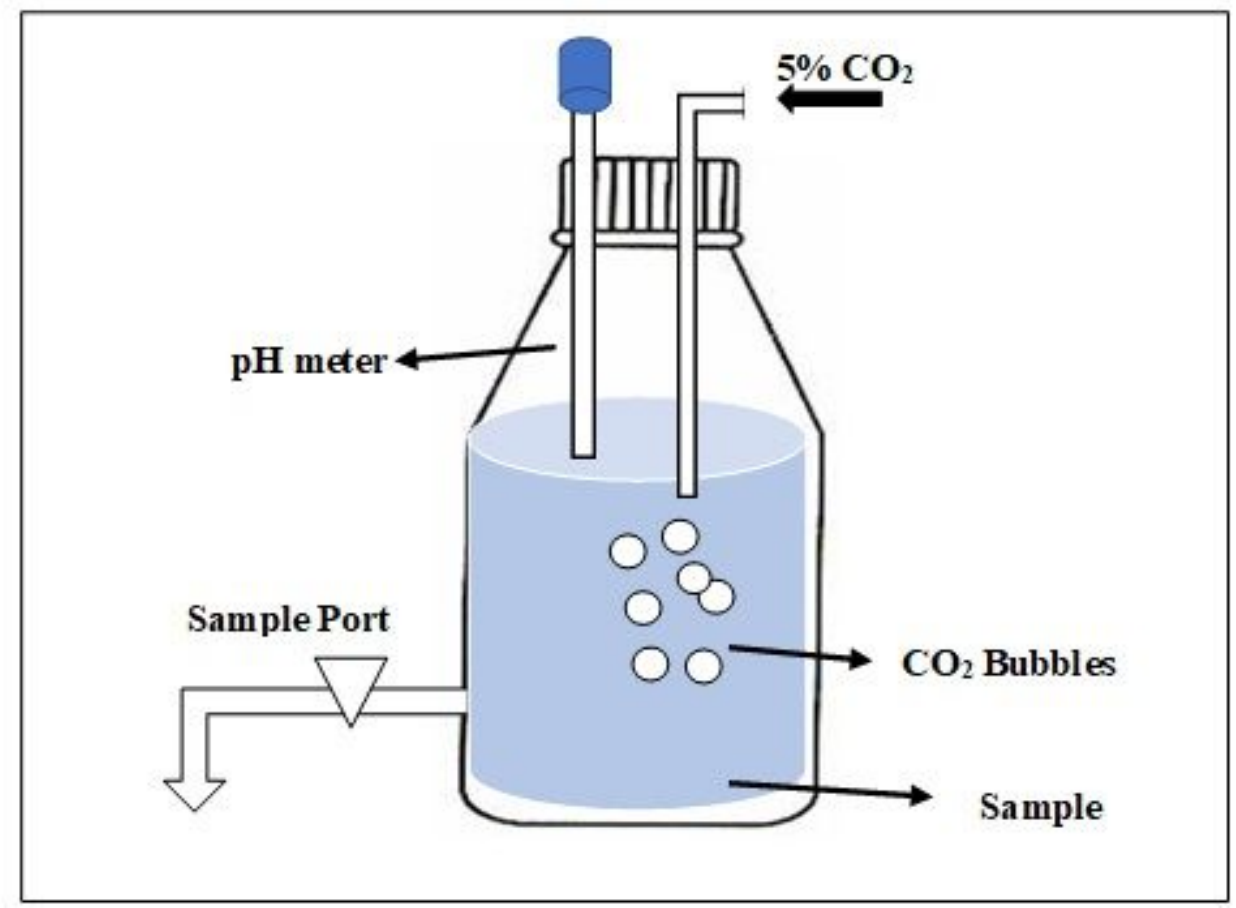

Figure 1

A schematic representation of dissolved free $\mathrm{CO} 2$ analysis
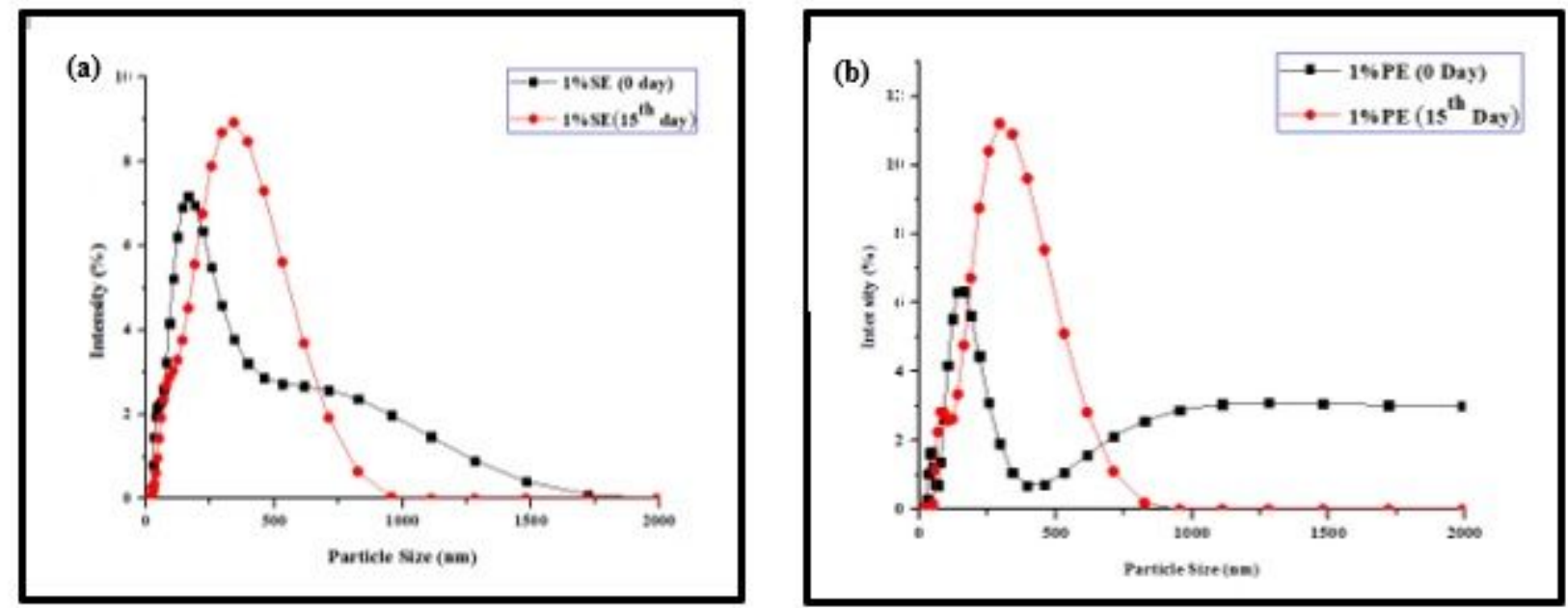

Figure 2

Comparison of droplet size distribution obtained from DLS for (a) $1 \%$ Silicone oil nanoemulsion (1\% SE) on 0th day and 15 th day (b) $1 \%$ Paraffin oil nanoemulsion (1\% PE) on 0th day and 15 th day 


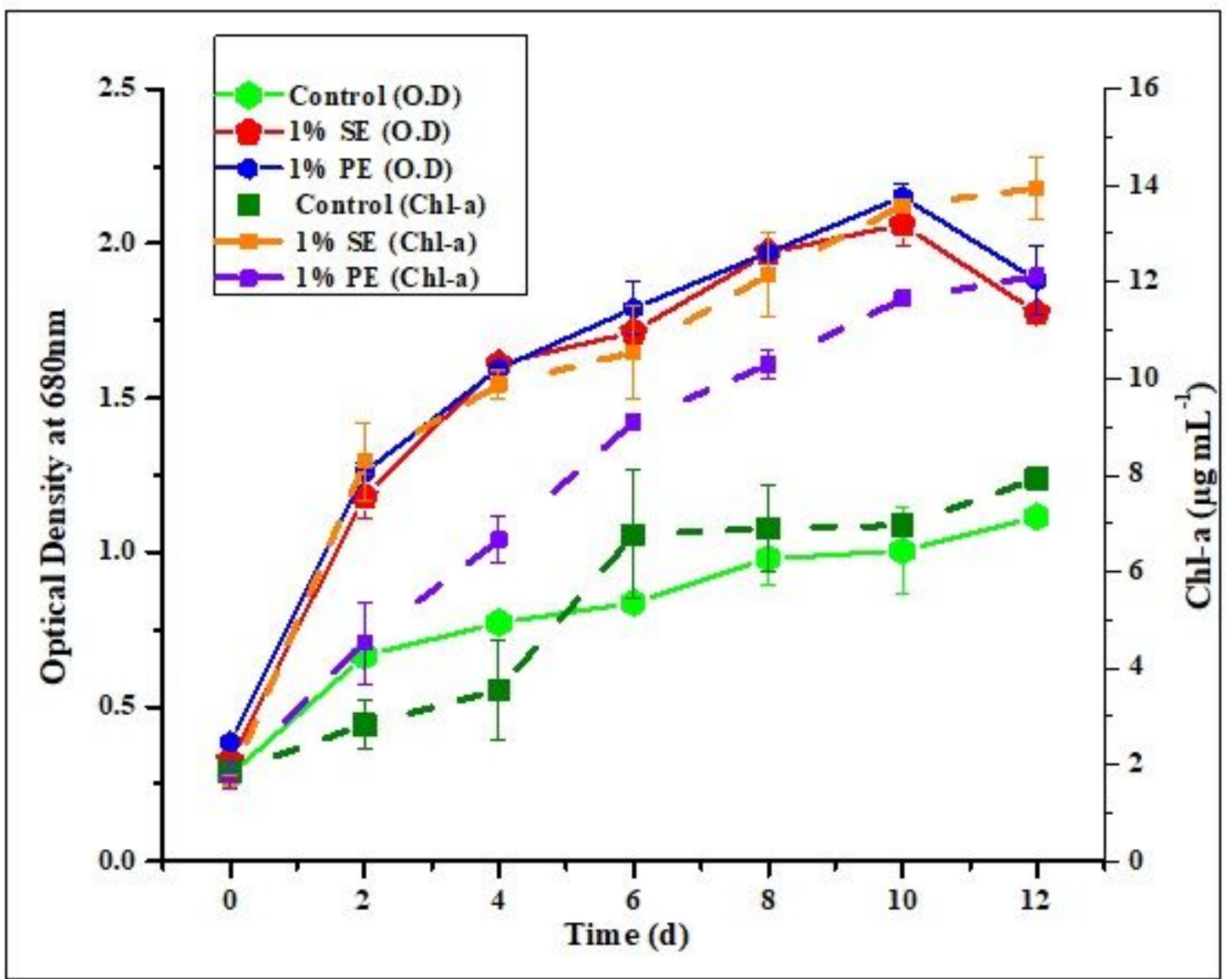

Figure 3

Growth profile and pigment synthesis of C. pyrenoidosa cultivated in 1\% Silicone oil nanoemulsion (1\% SE) and 1\% Paraffin oil nanoemulsion (1\% PE) compared with control (BG11) in terms of OD680 and ChIa content. Solid lines in the figure represent optical density and broken lines display Chl- a synthesis. The microalgal growth and pigment synthesis were measured every 48 hours up to 12 days. The cultures were operated at $25 \pm 1{ }^{\circ} \mathrm{C}$ with $\sim 46.5$ to $50 \mu \mathrm{mol} \mathrm{m}-2 \mathrm{~s}-1$ light intensity for 12 days. The data shown are the average of two data points, and error bars represent standard deviation. Data followed by an asterisk (*) are significantly different from control ( $p<0.005$, analyzed by t-test). 


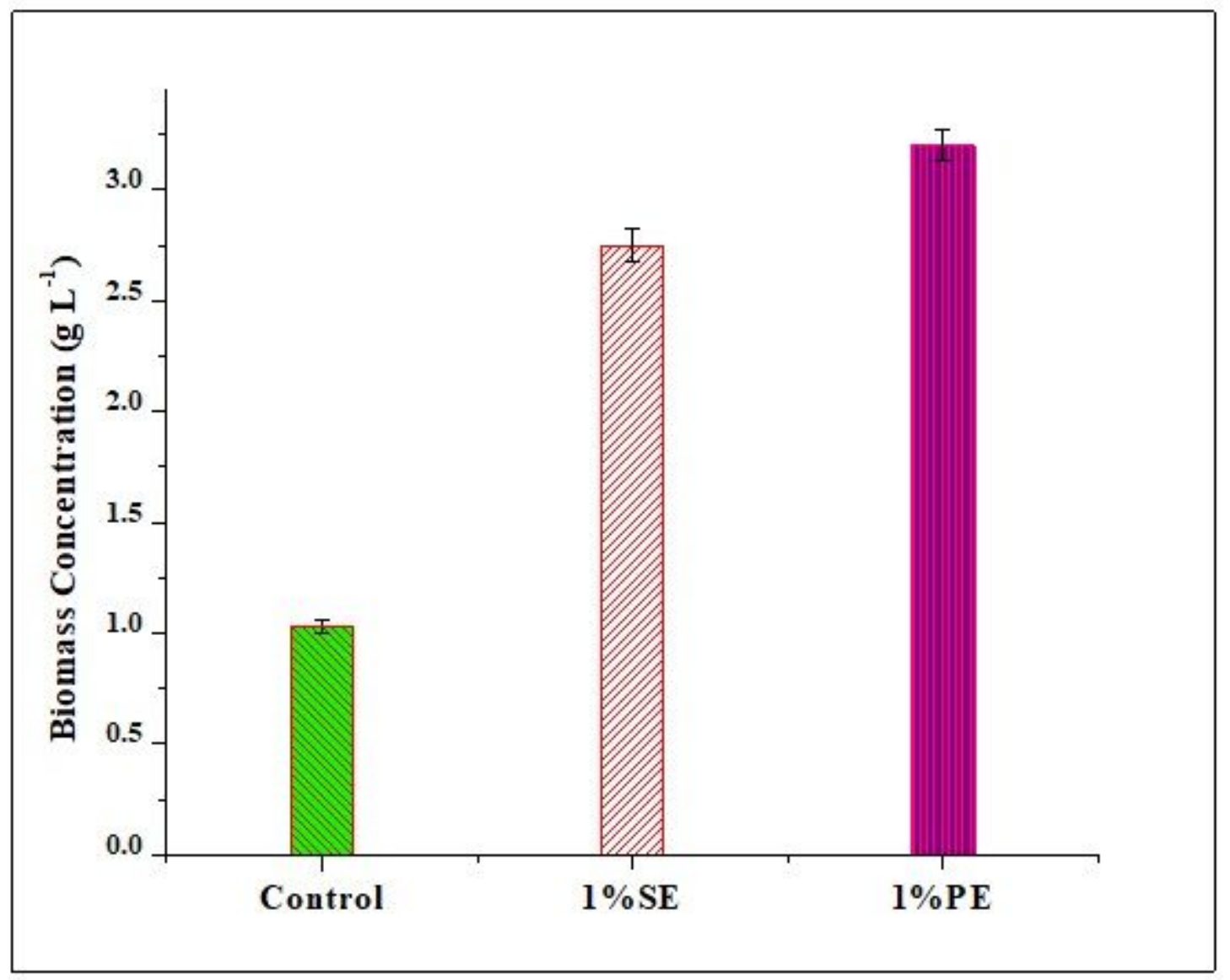

Figure 4

Growth profile of C. pyrenoidosa was observed in terms of biomass yield (g L-1) in 1\% Silicone oil nanoemulsion (1\% SE), 1\% Paraffin oil nanoemulsion (1\% PE), and control (BG11). The cultures were operated at $25 \pm 1{ }^{\circ} \mathrm{C}$ with $\sim 46.5$ to $50 \mu \mathrm{mol} \mathrm{m}-2 \mathrm{~s}-1$ light intensity for 12 days. The data shown are the average of two data points, and error bars represent standard deviation. Data followed by an asterisk (*) are significantly different from control $(p<0.005$, analyzed by $t$-test). 


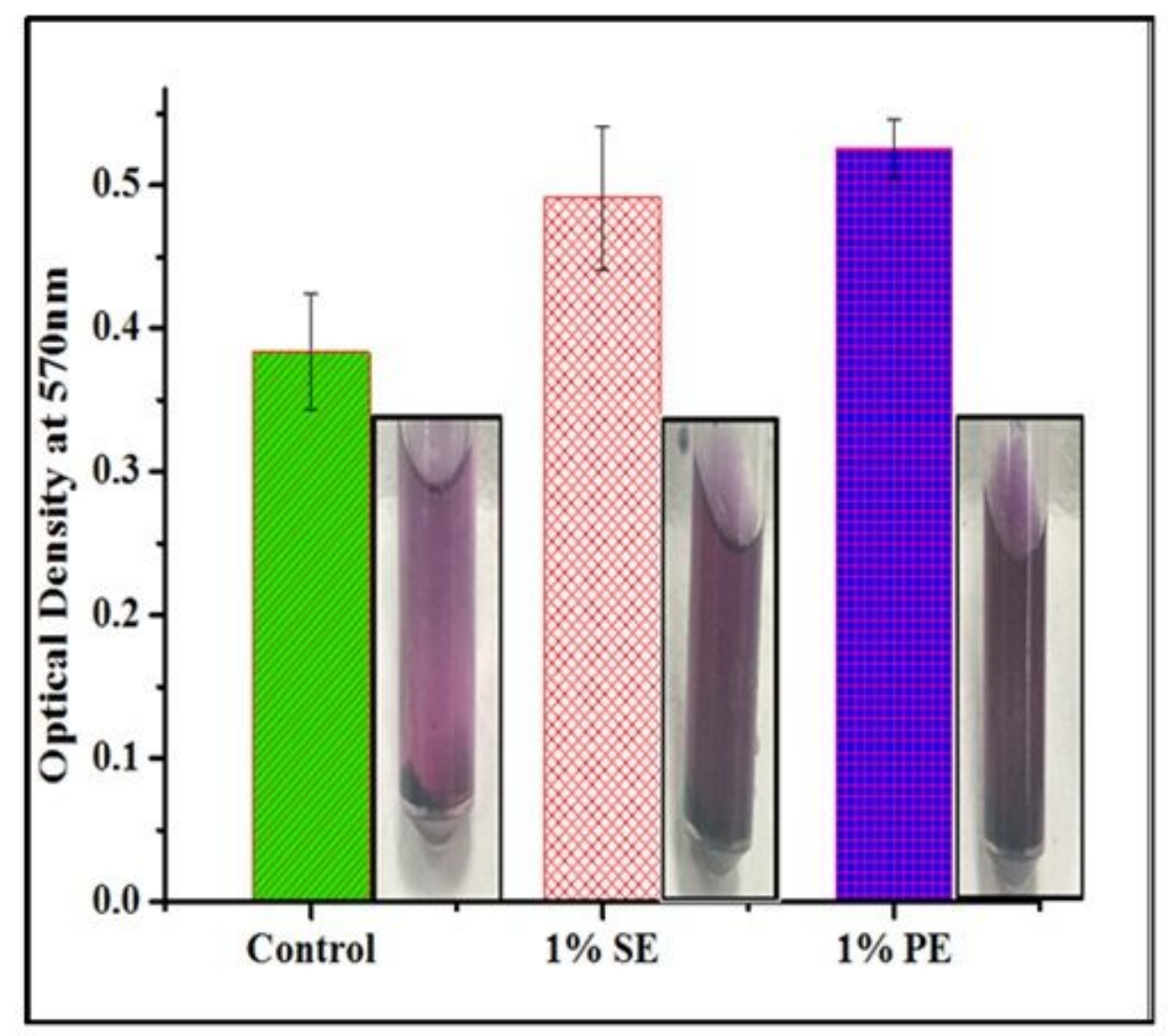

(a)
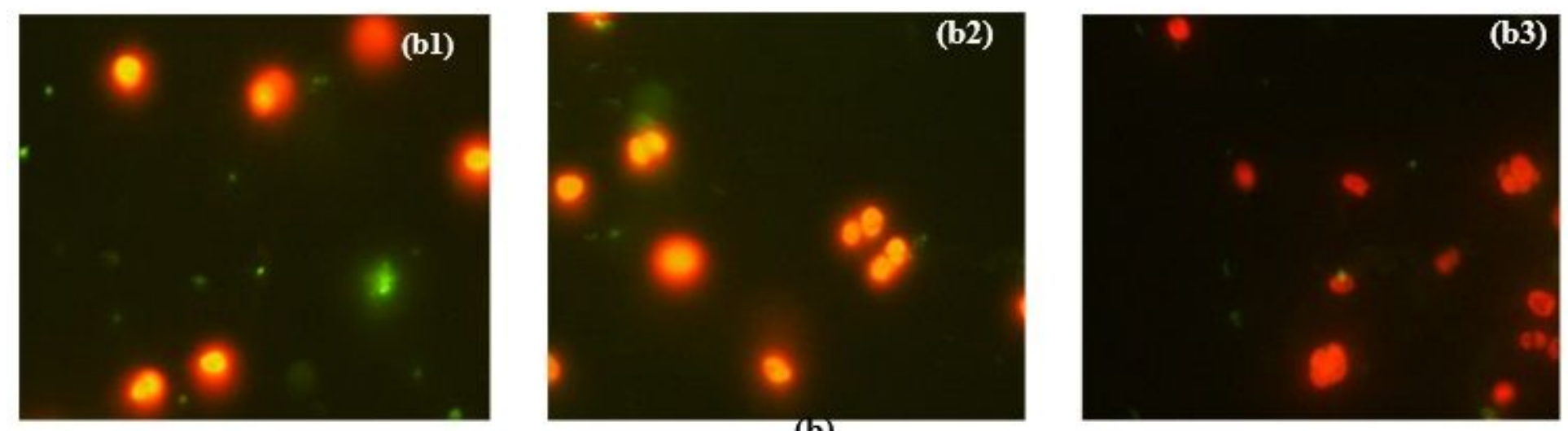

(b)

\section{Figure 5}

Microalgal cell viability analysis using MTT assay and SYTOX $®$ Green method (a) MTT result comparison of control (BG 11), 1\% Silicone oil nanoemulsion (1\% SE) and 1\% Paraffin oil nanoemulsion $(1 \% \mathrm{PE})$ in terms of optical density at $570 \mathrm{~nm}$ with corresponding vials showing purple formazan during the MTT Assay. Dark purple color represents greater cell viability. Errors bars are shown \pm SD in MTT analysis. (b) SYTOX ® Green stained fluorescent micrographs of C. pyrenoidosa to differentiate live and 
dead cells (b1) control (BG 11) (b2) 1\% Silicone oil nanoemulsion (b3) 1\% Paraffin oil nanoemulsion. Live cells appear red while dead cells appear green in color.

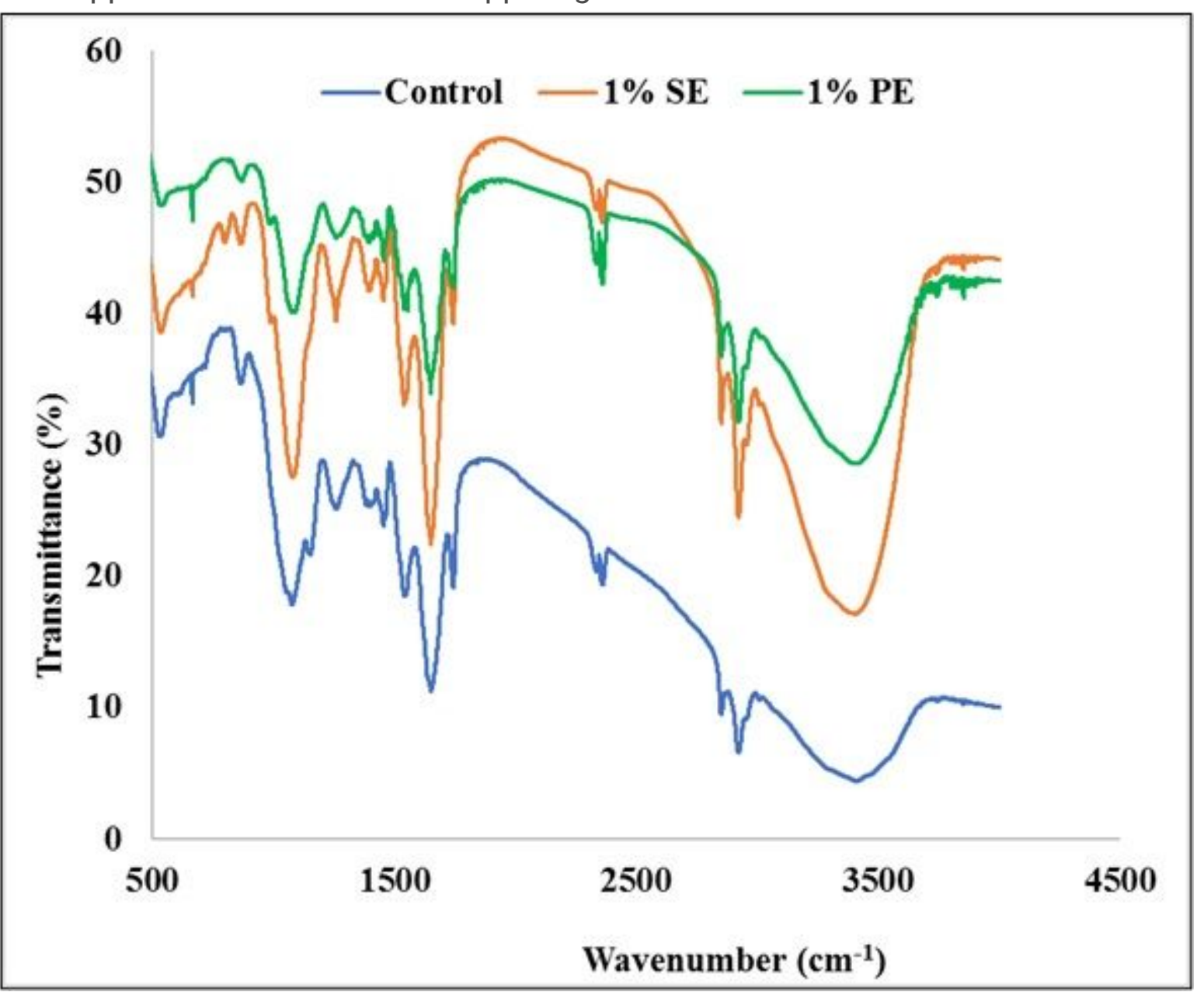

Figure 6

FTIR spectra of C. pyrenoidosa biomass obtained from control (BG 11), 1\% Silicone oil nanoemulsion (1\% $\mathrm{SE})$, and $1 \%$ Paraffin oil nanoemulsion (1\% PE) with different functional groups. 

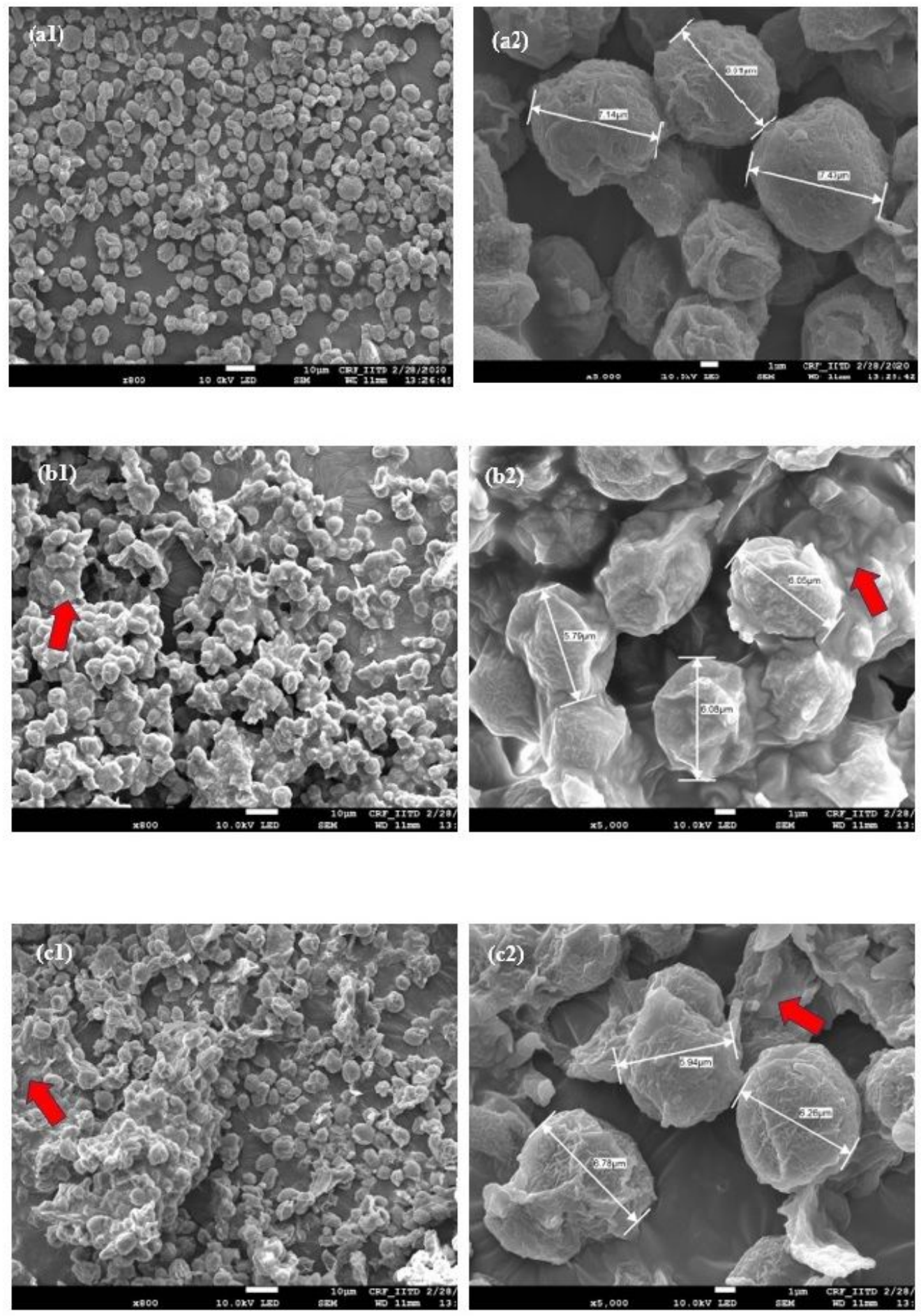

\section{Figure 7}

Field-emission scanning electron microscopy images of C. pyrenoidosa. Micrographs of BG 11 (control) cultivated C. pyrenoidosa at (a1) 800x magnification; (a2) 5000x magnification. Micrographs of $1 \%$ Silicone oil nanoemulsion (1\% SE) cultivated C. pyrenoidosa at (b1) 800x magnification; (b2) 5000x magnification. Micrographs of $1 \%$ Paraffin oil nanoemulsion (1\% PE) cultivated C. pyrenoidosa at (c1) 800x magnification; (c2) 5000x magnification. 


\section{Supplementary Files}

This is a list of supplementary files associated with this preprint. Click to download.

- GraphicalAbstract.png

- Supplementary.pdf 